\title{
Cuito Cuanavale - Wie het werklik Gewen? 'n Strategiese en Operasionele Ontleding
}

\author{
DR LEOPOLD SCHOLTZ \\ Departement Geskiedenis, Universiteit van Stellenbosch ${ }^{*}$
}

\section{ABSTRACT}

The Angolan campaign of 1987-'88 came as the culmination of a long and bitter war between South Africa and Swapo. Although South Africa's underlying intention was to limit Swapo's guerilla war to the territory of Ovambo, this could only succeed if the Angolan rebel movement Unita could continue covering the southeastern part of Angola. It was, therefore, in South Africa's interest to prevent Unita from being removed from the equation by the massive MPLA offensive of late winter and spring 1987. This was the basic reason for the country's intervention with Operation Moduler. The operation was, however, run with excessive operational control from Pretoria. Instead of allowing the officers on the ground a classic Liddell Hartian indirect approach by marching northwards west of the Cuito river to cut the advancing MPLA forces from their logistical hinterland and dislocating their offensive by attacking them from behind, Pretoria forced them into a direct head-on approach east of the river. The reason was to keep the South African involvement secret or, at the very least, 'plausibly deniable' - a naïve expectation. This did indeed result in a spectacular South African tactical victory at the Lomba River, where the MPLA offensive was decisively beaten back. But thereafter the South African forces were forced into a series of frontal attacks on increasingly well prepared MPLA defensive positions, including three final attacks on well fortified positions at Tumpo, which were beaten back, resulting in a subsequent stalemate. The stalemate was then brilliantly broken by Cuban forces, who marched to the southwestern 
Namibian border, threatening to cut the South Africans off at Tumpo, or alternatively to invade Namibia. The campaign is analysed in the light of military theory, especially the ideas of Clausewitz and Liddell Hart. The conclusion is that the MPLA lost badly, that South Africa reached its strategic objectives but did badly operationally, and that Cuba came out of the affair with flying colours.

\section{INLEIDING}

Tussen September 1987 en Julie 1988 was Suid-Afrikaanse soldate betrokke by die mees intense en grootskaalse gevegte wat hulle sedert 1945 gevoer het, toe 6 SA Pantserdivisie deel van die Geallieerde offensief teen die Duitse magte in Italië was. Dit was die veldtog in Angola teen eenhede van die Angolese en Kubaanse leër, wat vir die Suid-Afrikaners op 'n reeks skitterende oorwinnings op die oewers van die Lombarivier uitgeloop het. Later het die veldtog vasgeval in 'n dooie punt naby Cuito Cuanavale. Dit het aanleiding gegee tot bewerings dat die SA Weermag ' $n$ vernederende nederlaag hier gely het, dat die Republiek daardeur na die onderhandelingstafel gedwing is en uiteindelik uit Angola moes padgee en onafhanklikheid aan Namibië moes verleen.

Verskeie boeke het intussen verskyn wat dié bewerings probeer weerlê het. Tog, al het die nuwe SA Nasionale Weermag dit dalk al intern gedoen, het geen publikasie vir openbare kennisname nog verskyn met die doel om die veldtog in die lig van algemeen aanvaarde strategiese en operasionele beginsels te ontleed nie.

Sedert die veldtog het die breë politieke situasie dramaties verander. Namibië het onafhanklik geword; die burgeroorlog in Angola is beëindig en die Kubane het padgegee; in Suid-Afrika is die mag aan 'n demokraties verkose regering oorhandig; en die Koue Oorlog het op 'n skouspelagtige ineenstorting van die Berlynse Muur, die Sowjet-Unie en die kommunisme as globale magsfaktor uitgeloop. 
Tog bly die noodsaak van so 'n ontleding belangrik, ten eerste ter wille van die krygsgeskiedenis, maar daarnaas ook ter wille van 'n behoorlike begrip van strategiese en operasionele beginsels by sowel die SANW as die Regering. Die strategiese teorie geniet klaarblyklik geen hoë status by baie hooggeplaaste offisiere in die SANW nie, mense vir wie die praktyk baie meer tel as die teorie. 'n Kursus in die strategie is byvoorbeeld eers in 1991 vir die eerste keer by die Militêre Akademie ingestel. ${ }^{1}$

Ofskoon daar tans geen militêre bedreiging teen die Republiek is nie, is die ná-Koue-Oorlogse internasionale situasie só onseker dat niemand met sekerheid kan voorspel dat dit op lang of selfs middellang termyn so sal bly nie. Dit is dus nodig dat sowel offisiere as politici - selfs in vredestyd - 'n behoorlike begrip moet hê van hoe om die Weermag as politieke instrument van die staat te hanteer. Dit is tot 'n begrip hiervan dat dié ontleding aan die hand van die Angolese veldtog as praktiese illustrasie ' $n$ bydrae wil lewer.

Dié studie handel oor die strategiese en operasionele vlak. Die taktiek kom slegs ter sprake waar dit operasies beïnvloed het.

Waar kritiek op beslissings uitgespreek word, is die doel pertinent nié om individue te na te kom nie. Die kritiek word in alle nederigheid uitgespreek, wel wetende dat 'n akademiese ontleding agter 'n lessenaar, en met die voordeel van agternakennis, maklik is. Om in die hitte van die oomblik beslissings te neem wat menselewens kan kos en waarvan selfs die toekoms van ' $n$ land afhang, is iets totaal anders.

Die vermaarde Pruisiese militêre filosoof Carl von Clausewitz sê immers: "As 'n mens nooit persoonlik oorlog ervaar het nie" - dit geld terloops ook vir die skrywer van dié studiestuk - "lyk alles eenvoudig; die kennis wat nodig is, lyk nie merkwaardig nie; die strategiese opsies is só vanselfsprekend dat selfs die eenvoudigste probleem van hoë wiskunde 'n indrukwekkende wetenskaplike waardigheid het." Maar dan waarsku hy in dieselfde asem: "In oorlog is alles eenvoudig, maar die eenvoudigste is baie moeilik." ${ }^{2}$ Dit om duidelik te maak dat die teorie maklik is, maar dat die uitvoering teen voortdurende praktiese probleme stuit. 
'n Woord oor begrippe: Die algemeen aanvaarde moderne onderskeid tussen strategie en operasie word in dié studie gehandhaaf; strategie synde handelinge op die oorlogspolitieke vlak, en operasie die gebruikmaking van troepemagte deur operasies en veldtogte om die bereiking van die strategiese doel naderby te bring. Taktiek, wat in dié studie nie werklik ter sprake kom nie, is die gebruikmaking van gevegte en skermutselings om die operasionele oogmerk te bereik. Ander begrippe in wat sommige waarnemers die strategiese kontinuum noem nasionale belange, nasionale veiligheidsbelange, nasionale veiligheidsbeleid en nasionale strategie $\mathrm{e}^{3}$ - is bo die vlak van dié studie.

'n Woord oor bronne: geen primêre navorsing kon gedoen word nie; die argivale bronne in Suid-Afrika, Angola en Kuba is nog geklassifiseerd. Die meeste feitelike materiaal is vervat in twee uitvoerige boeke, dié van die Britse joernalis Fred Bridgeland en die Suid-Afrikaanse konsultant Helmoed-Römer Heitman. ${ }^{4}$ Bykomende feite en insigte is verkry uit 'n boek oor Suid-Afrika se grensoorlog deur die joernalis Willem Steenkamp ${ }^{5}$, uit genl. Jannie Geldenhuys se herinneringsgeskrif ${ }^{6}$ en koerantnavorsing. Dié basiese feite is egter opnuut georden en deur die bril van die moderne krygswetenskap bekyk. Die doel is in elk geval nie om enige nuwe feitelike onthullings oor die gebeure van meer as 'n dekade gelede te doen nie. Die doel is om 'n nuwe vertolking van die reeds bekende feite te verskaf. Of die gevolgtrekkings juis is, is vir ander om te oordeel.

\section{DIE AANLOOP}

Om die strategiese analise behoorlik te begryp, is 'n kort uiteensetting van die aanloop tot die veldtog noodsaaklik. Suid-Afrika se militêre betrokkenheid in Angola het in der waarheid al in 1975 begin, toe hy stap vir stap, en eintlik teen sy wil, in die burgeroorlog in Angola ingesuig is. Die destydse regering van premier John Vorster wou nie soos Amerika in

Vgl. J.S. Kotzé: "Die Strategiese Kontinuum: Raamwerk vir 'n Studie van Suid-Afrikaanse Strategie in die Namibiese Konflik" (Joernaal vir Eietydse Geskiedenis, 19/3, Des. 1994, pp. 36-61.)

$4 \quad$ Fred Bridgeland: The War for Africa, Twelve Months that Transformed a Continent; HelmoedRomer Heitman: War in Angola, the Final South African Phase.

Willem Steenkamp: South Africa's Border War, 1966-1989.

Jannie Geldenhuys: Dié wat wen, 'n Generaal se storie uit 'n era van oorlog en vrede. 
'n Viëtnam-agtige moeras ingetrek word nie. Maar deur die sameloop van omstandighede, asook die aandrang van die Ford-administrasie in Washington, Afrika-state soos Zaïre en Zambië en Unita in Angola, het hy uiteindelik in 'n skouspelagtige veldtog - aanvanklik klandestien, later al hoe openliker - betrokke geraak. Deur die inmenging van 'n groot Kubaanse mag en die feit dat die Amerikaanse Kongres die Wit Huis gedwing het om sy politieke en logistieke steun aan Suid-Afrika, Unita en die FLNA te staak, is die Republiek egter geïsoleer en het hy hom vroeg in 1976 aan Angola onttrek. ${ }^{7}$

Dié - soos dit ervaar is - politieke onbetroubaarheid van Amerika het 'n diep indruk op die Suid-Afrikaanse regering en die Weermag gemaak. Nooit weer, so het die Suid-Afrikaners hulself voorgeneem, sou hulle toelaat dat die land in 'n situasie kom waar hy, sonder dat sy eie belange beslissend geraak word, by 'n ander man se oorlog betrokke raak en uiteindelik voor die hele wêreld as die boosdoener verneder word nie. Dié erfenis sou 'n besliste uitwerking op die veldtog van 1987-'88 hê.

Die veldtog van 1975-'76 het sowel strategies as operasioneel (en dikwels takties ook) 'n offensiewe postuur aan Suid-Afrika verleen. Die steeds intensiewer wordende teeninsurgensie-oorlog teen Swapo in die noorde van die destydse Suidwes-Afrika was daarenteen strategies defensief, maar in die lig daarvan dat die Weermag meestal die inisiatief in die stryd behou het, moet sy postuur hier in sekere sin as operasioneel en takties offensief beskou word.

Die Weermag het nietemin geoordeel dat hy die stryd nie kon wen as hy Swapo toelaat om die inisiatief selfs gedeeltelik te neem nie. In Desember 1977 het Vorster dus saam met 'n groep senior offisiere besluit om tot die offensief oor te gaan. Dit het op die groot valskerm-aanval op die Swapo-basis by Cassinga en ' $n$ landaanval op basisse in die omgewing van Chetequera uitgeloop. ${ }^{8}$ Dié aanvalle het die model geword vir 'n reeks offensiewe deur die jare wat Suid-Afrika strategies steeds in 'n verdedigende postuur geplaas het, maar operasioneel en takties offensief - die oorlogsvorm wat volgens een vertolking van Clausewitz se denke

Vgl. hieroor F.J. du T. Spies: Angola, Operasie Savannah; Sophia du Preez: Avontuur in Angola, die verhaal van Suid-Afrika se soldate in Angola 1975-1976.

Vgl. hieroor Willem Steenkamp: Borderstrike! South Africa into Angola. 
die sterkste is. ${ }^{9}$ Dié reeks aksies was primêr teen Swapo gerig. Skermutselings het wel af en toe met die Angolese leër, Fapla, voorgekom, maar hulle was insidenteel. In die loop van die jare tagtig is Suid-Afrika egter langsaam maar seker opnuut in die burgeroorlog ingesuig.

In 1981 (twee keer), 1982 en 1983 het Fapla swak georganiseerde en beplande offensiewe teen Unita se gebied in Suidoos-Angola van stapel laat loop. Dié offensiewe het van 'n totale gebrek aan operasionele insig en verbeelding getuig: hulle het meestal dieselfde, voorspelbare roete van Menongue en Cuito Cuanavale in die noorde in die rigting van Mavinga in die suidooste gevolg, en is almal maklik teruggeslaan. "Soviet-led FAPLA offensives bore little relation to Angolan conditions," was die oordeel van dr. Chester Crocker, Amerikaanse assistent-minister van buitelandse sake belas met Afrika, Amerika se hoofonderhandelaar insake Angola en Namibië. "The arts of surprise and mobility were as alien to Soviet planning as the concept of logistics was to the Angolans." 10

In 1985 het Fapla weer dieselfde gedoen, maar ofskoon dieselfde roete wéér gevolg is, het dit dié keer met 'n groot oormag aan troepe en wapentuig gepaard gegaan. Op versoek van Unita het Suid-Afrika dus artillerie-raadgewers en mediese personeel, logistieke steun en 'n troep veelvoudige vuurpyllanseerders na die front gestuur. 'n Beperkte, maar verwoestende lugaanval is ook met Mirage F1AZ's en Impala II's op 'n Fapla-konvooi aan die Lombarivier gedoen. Die jaar daarop, in 1986, het dieselfde vrugtelose offensief weer gevolg. "

Toe die SAW se Inligtingsdiens dus teen Julie 1987 opnuut aanduidings van voorbereidings vir ' $n$ hernieude offensief van Fapla teen Unita kry, was die Weermag op twee maniere in Angola betrokke, al het hulle prinsipieel van mekaar verskil: oorgrens-operasies teen Swapo, hoofsaaklik in die gebied reg noord van Ovambo, en 'n baie beperkte betrokkenheid - hoofsaaklik die lewering van wapentuig en ander voorrade - aan Unita. Dié keer sou dit egter anders word.

Vgl. Jehuda L. Wallach: Das Dogma der Vernichtungsslacht, die Lehren von Clausewitz und Schlieffen und ihre Wirkungen in zwei Weltkriegen, p. 41.

Chester A. Crocker: High Noon in Southern Africa, Making Peace in a Rough Neighborhood, p. 356.

Heitman: War in Angola, pp. 10-19. 


\section{WAT DIE TEORIE VEREIS}

Om die veldtog behoorlik strategies en operasioneel te kan waardeer, is dit nodig om eers iets oor die teorie van die saak te sê. Dit was Clausewitz wat waarskynlik die beste intellektuele ordening van die verhouding tussen oorlog en politiek gegee het. Sy sentrale tese is bekend: "Oorlog is 'n voortsetting van die politiek met ander middele." Agter dié stelling skuil egter 'n hele filosofiese gedagtestelsel en dit sal die moeite loon om dit van naderby te bekyk.

As basiese uitgangspunt hanteer Clausewitz die stelling dat oorlog ' $n$ politieke wilsdaad is en dat dit as maatskaplike verskynsel nie van die politiek onderskei kan word nie. Hy gebruik 'n treffende beeld: die grammatika van die oorlog en die politiek kan dalk verskil, maar nie die intrinsieke logika waardeur hulle as verskynsels begryp moet word nie. ${ }^{12}$ Gevolglik is oorlog nie slegs 'n politieke daad nie, "maar 'n egte politieke instrument, 'n voortsetting van die politieke verkeer, 'n voorsetting daarvan met ander middele."13

Dit volg dus logies dat die politieke opgawe die doel van 'n oorlog vorm en die oorlog self slegs die middel om die doel te bereik. Die oorlog is gevolglik duidelik ondergeskik aan die politiek, "want die politiek het die oorlog voortgebring; die politiek vorm die intelligensie, terwyl die oorlog bloot die instrument is, en nie omgekeerd nie". ${ }^{14}$

Hieruit kristalliseer daar dus 'n belangrike gesigspunt waaraan enige krygsplan - trouens, enige krygshandeling - gemeet moet word: dit dien om ' $n$ bepaalde politieke doel te bereik, en daarom is elke krygshandeling met politieke oorwegings verweef. Daarom kan daar geen "suiwer militêre" beoordeling van 'n militêre daad wees nie. Aangesien die strategie en die operasie onderhewig aan die politiek is, moet daar gekyk word in welke mate die krygshandelinge die bereiking van die politieke doel dien.

Wat is nou dié politieke doel? Clausewitz sê hieroor dat "oorlog 'n daad van geweld is ... om ons teenstanders te dwing om ons wil te

Clausewitz: On War, VIII/6, p. 125.

Ibid., 1/1, p. 23.

Ibid., VIII/6, p. 125. 
doen". ${ }^{15}$ En uitgaande van die primaatskap van die politiek, moet "ons wil" uiteraard deur die regering van die dag bepaal word.

Wat "ons wil" - die oorlogsdoel - is, kan natuurlik in die lig van veranderde omstandighede gewysig word. Die invloedryke Britse militêre denker sir Basil Liddell Hart sê dat "the government, which formulates war policy, and has to adapt it to conditions which often change as a war pogresses, can rightly intervene in the strategy (operations) of a campaign ... by modifying his object according to the needs of its war policy". ${ }^{16}$

Die vraag is nou hóé om "ons wil" aan die vyand op te dwing. Hieroor het Clausewitz verskeie, soms teenstrydige uitsprake gedoen. Soms lyk dit of hy die vernietiging van die vyand in die veld as hoogste doel bepleit; ander kere praat hy van die "politieke vernietiging of bloot die weerloos maak" van die vyand. Dat hy egter soepel oor die saak dink, blyk daaruit dat hy "baie weë na die doel van 'n oorlog" sien en dat "die totale onderwerping van die vyand nie in alle gevalle noodsaaklik is nie." ${ }^{\prime 7}$ Dié aspek is egter nie Clausewitz se sterk punt nie; daarvoor moet ons ons eerder op ander skrywers verlaat.

Waar Clausewitz betreklik vaag hieroor is, is Liddell Hart skerp en duidelik: Die doel van strategie (lees: die operasionele kuns), skryf hy, is nie om weerstand te oorwin nie. "Its purpose is to diminish the possibility of resistance ..."18 (Liddell Hart gebruik nog die verouderde indeling van "grand strategy", "strategy" en "tactics", wat sedert die Tweede Wêreldoorlog wêreldwyd vervang is met strategie, operasionele kuns en taktiek.)

Liddell Hart is as jong offisier op die Wesfront in Frankryk in die Eerste Wêreldoorlog blootgestel aan die dom en sinlose operasies aan albei kante ingevolge waarvan die vyand deur massale frontaanslae aangeval is juis op plekke waar hy sterk en goed ingegrawe was. Begerig om bloedvergieting te help voorkom deur 'n veel intelligenter en subtieler benadering tot oorlogvoering, het hy tot dié gevolgtrekking gekom: "Let us assume that a strategist is empowered to seek a military decision. His responsibility is to seek it under the most advantageous circumstances in

Ibid., 1/1, p. 3. Vgl. ook 1/2, p. 27.

B.H. Liddell Hart: Strategy, p. 337.

Clausewitz: On War, $1 / 2$, p. 27; $1 / 1$, p. $5 ; 1 / 2$, p. 35. 
order to produce the most profitable result. Hence his true aim is not so much to seek battle as to seek a strategic situation so advantageous that if it does not of itself produce the decision, its continuation by battle is sure to achieve this. In other words, dislocation is the aim of strategy (sic); its sequel may either be the enemy's dissolution or his easier disruption in battle." 19 Dit is sy "indirect approach", waarvoor hy wye bekendheid onder studente van oorlogvoering verwerf het.

Daar is ewenwel 'n selfs nóg hoër ideaal. "The perfection of strategy," sê Liddell Hart, "would be, therefore, to produce a decision without any serious fighting," en hy noem dan 'n aantal historiese voorbeelde waar dit gebeur het. Teen dié agtergrond, sê hy, kan weerstand vermy word deur "the line of least resistance" te volg, wat in psigologiese opsig dan ook "the line of least expectation" is. ${ }^{20}$

Toe Liddell Hart sy idees in die jare twintig begin verkondig het, was dit vir baie mense 'n openbaring. Maar dit was in der waarheid slegs die herontdekking van ou waarhede. Die Chinese militêre wysgeer Sun Tzu het 'n paar eeue voor Christus al soortgelyke wyshede kwytgeraak, soos: "Diegene wat elke veldslag wen, is nie regtig vernuftig nie - dié wat ander se leërs hulpeloos maak sónder om te veg is die beste van almal." En: "Val aan wanneer hulle onvoorbereid is, mak jou skuif wanneer hulle dit nie verwag nie.,"21

Selfs die Saksies-Franse maarskalk Maurice de Saxe het dit in die agtiende eeu so gestel: "Ek is nie ten gunste van groot gevegte nie ... en ek is daarvan oortuig dat ' $n$ vernuftige generaal sy hele lewe lank oorlog kan voer sonder om in een ingedwing te word. Niks reduseer die vyand só tot absurditeit as dié metode nie; niks bevorder jou saak meer nie."22

Dié teoretiese insigte kan ons nou help om die veldtog in Angola behoorlik te beoordeel.

Liddell Hart: Strategy, p. 337.

Ibid., p. 339. Liddell Hart se kursivering.

Ibid., pp. 338 en 341 . My kursivering.

Sun Tzu: The Art of War, pp. 67 en 54.

Aangehaal in Adrian Liddell Hart (red.): The Sword and the Pen, Selections from the world's greatest military writings, p. 92 . 


\section{DIE STRATEGIESE DOEL}

Soos hierbo gestel is, het die slegte politieke afloop van die Angolese veldtog van 1975-'76 die Suid-Afrikaanse regering uiters skrikkerig vir 'n hernieude betrokkenheid by die Angolese burgeroorlog gemaak. Dat troepe van die SAW gereeld in oorgrens-operasies in Angola bedrywig was, was prinsipieel anders: dit was operasies teen Swapo, en spesiale moeite is gedoen om gevegte met Fapla te vermy, al het botsings soms wel plaasgevind. Dit wil nie sê dat Suid-Afrika heeltemal belangeloos by die burgeroorlog was nie; hy had wel deeglik belang by die voortbestaan van Unita as militêre politieke faktor. In 'n persverklaring op 20 September 1985 het die Minister van Verdediging, genl. Magnus Malan, vir die eerste keer die bestaan van "materiële, humanitêre en morele" bande tussen die Republiek en Unita toegegee. Die doel daarvan, het hy gesê, was die stopsit van buitelandse inmenging deur Kubane en ander kommunistiese magte, asook van Marxistiese infiltrasie en uitbreiding. ${ }^{23}$

Vir Suid-Afrika was twee sake wat ten nouste met mekaar saamgehang het op die spel - die Kubaanse aanwesigheid in Angola en die moontlikheid dat Swapo die bewind in Windhoek deur ' $n$ militêre oowinning kon oorneem. Die Kubaanse inmenging was inderdaad steeds vir die Regering 'n groot bron van kommer, en hy het al sedert 1981 die onttrekking van die Kubaanse troepe uit Angola as voorvereiste vir sy eie medewerking met Resolusie 435 - die onafhanklikwording van Namibië dus - gestel.

Die stryd teen Swapo was in Julie 1987, toe die omvang van Fapla se voorbereidings vir sy opmars na die suide duidelik begin word, egter van meer onmiddellike belang. Teen die jare tagtig het die SAW daarin geslaag om Swapo se insurgensie in Namibië feitlik heeltemal tot Ovambo te beperk. Waar dié organisasie vroeër ook in die Kaokoveld, Okavango en die Caprivi-strook doenig was, was sy vegters teen die helfte van die jare tagtig heeltemal uit dié gebiede weggedryf. Dit was 


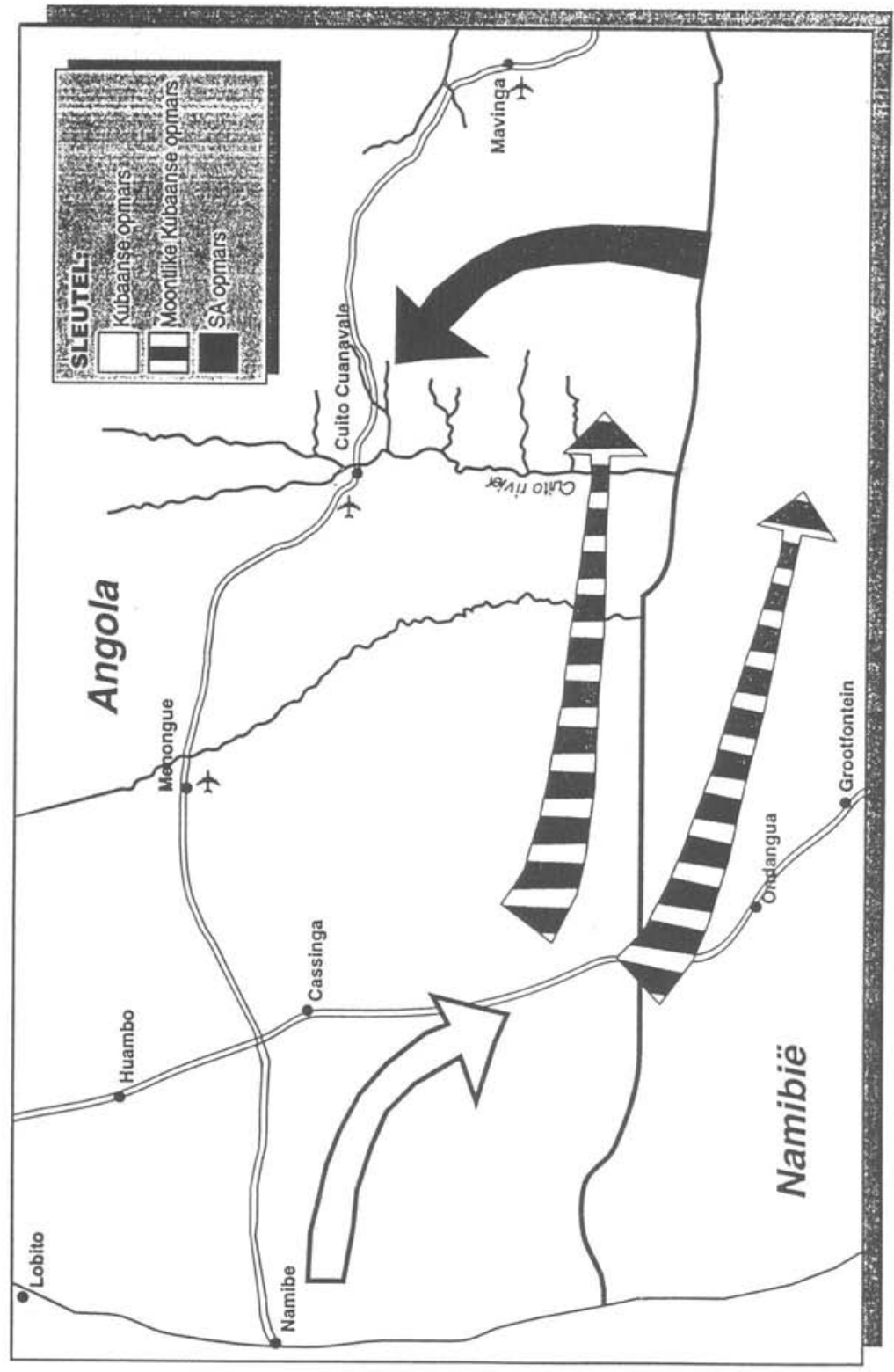


Scientia Militaria, South African Journal of Military Studies, Vol 28, $\mathrm{Nr} 1,1998$. http://scientiamilitaria.journals.ac.za

ธิน!ฺq

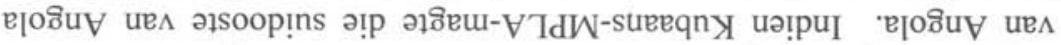

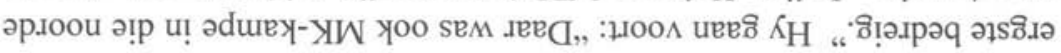

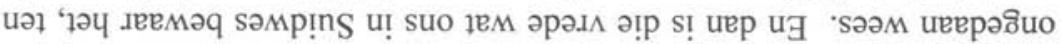

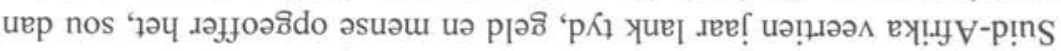

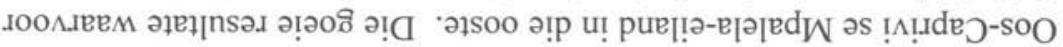

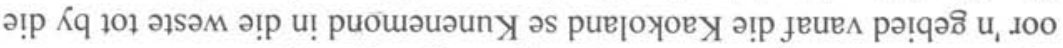

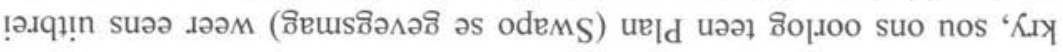

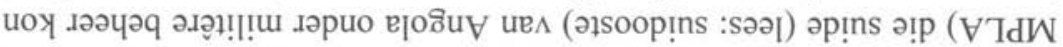

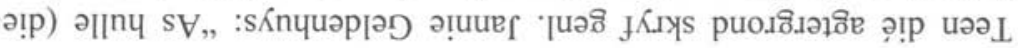

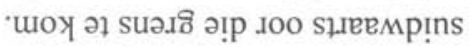

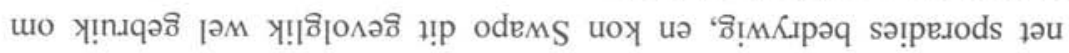

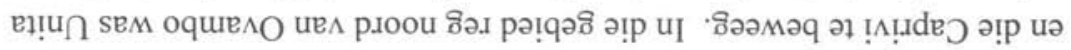

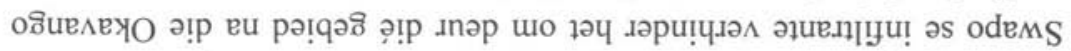

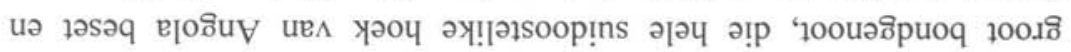
әs ex!.J

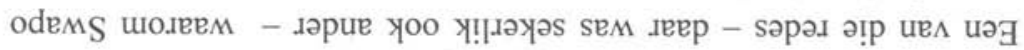

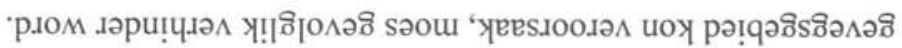

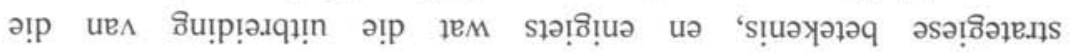

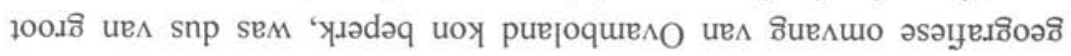

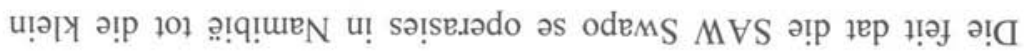

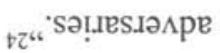

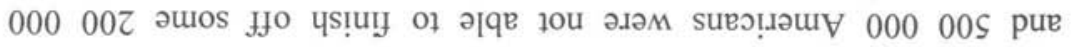

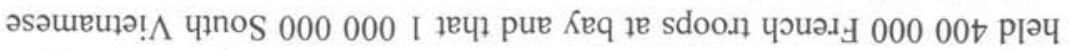

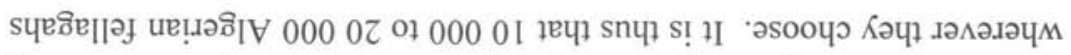

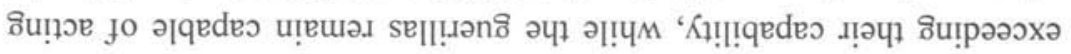

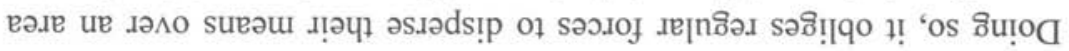

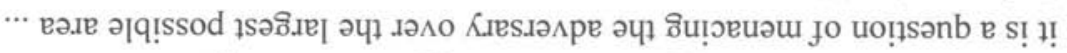

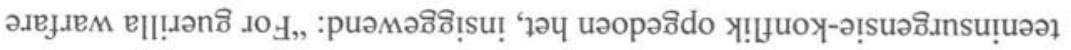

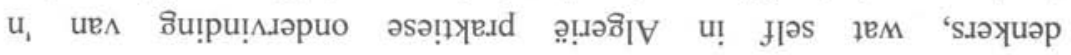

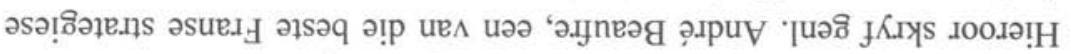

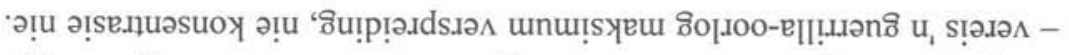

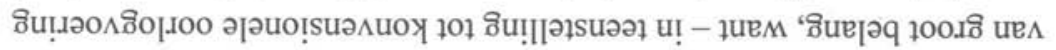




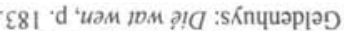

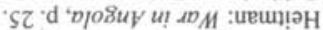

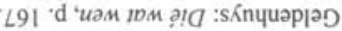

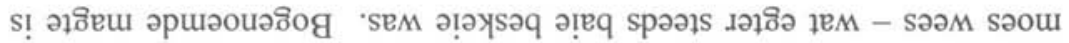

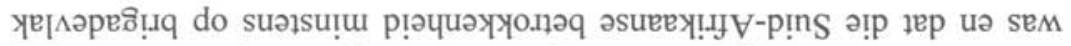

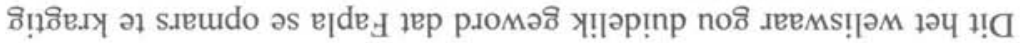

$\cdot \mathrm{xnn}$

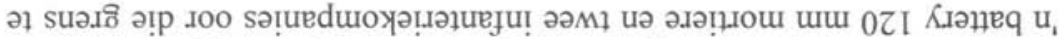

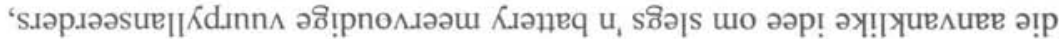

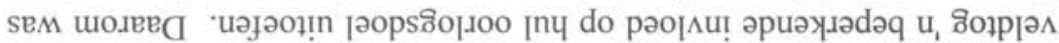

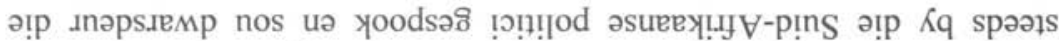

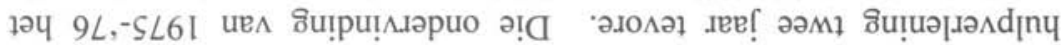
әsuеEx!! ү.ədəq sәрә. әуә!!!

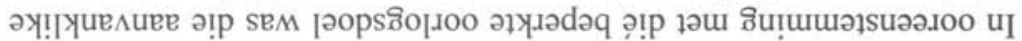

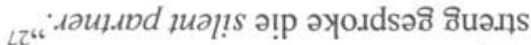

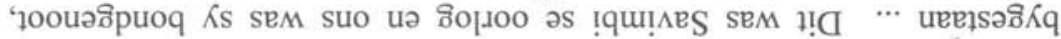

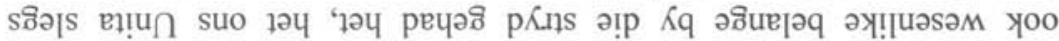

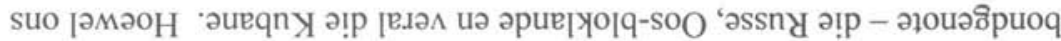

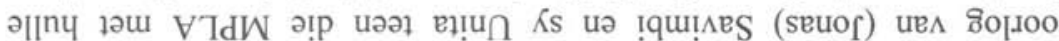

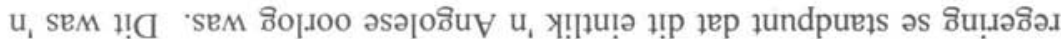

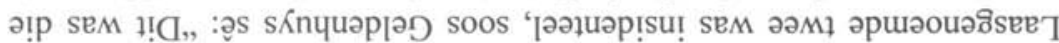

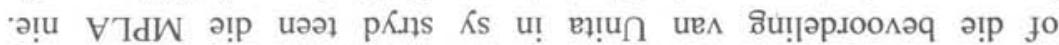

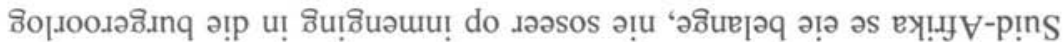

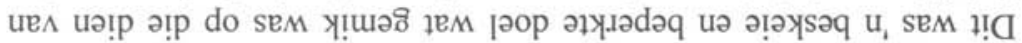

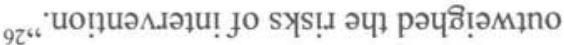

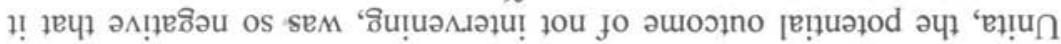

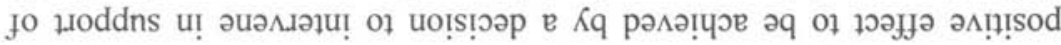

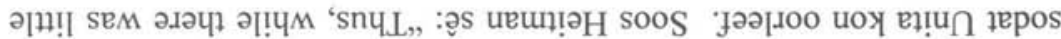

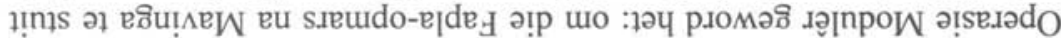

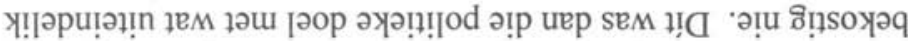
ә!u snp .оңяе әуә!!!

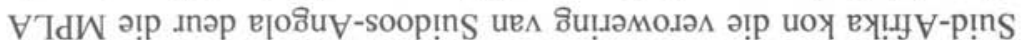
•ə૫ ә!s!

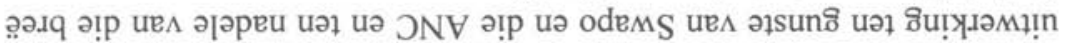

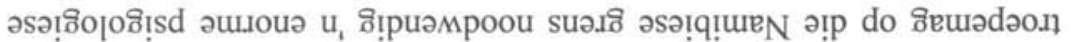

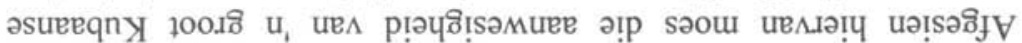

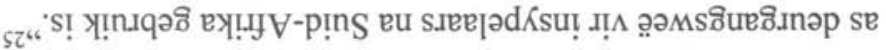

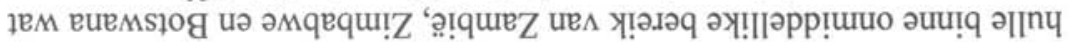


Scientia Militaria, South African Journal of Military Studies, Vol 28, $\mathrm{Nr} 1,1998$. http://scientiamilitaria.journals.ac.za

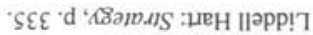
$t \tau-\varepsilon Z$ 'dd ' $\mathrm{I} / \mathrm{I}$ " $\mathrm{p!q}$

$11 \cdot \mathrm{d}$ '1/I '

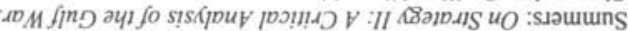

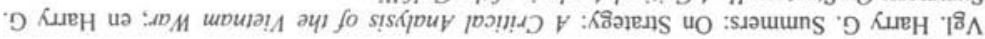

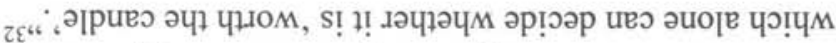

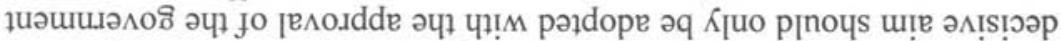

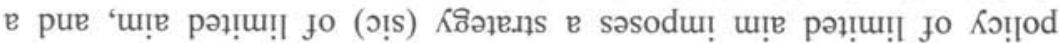

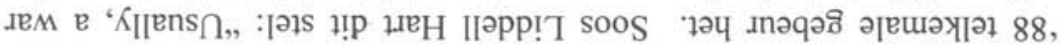

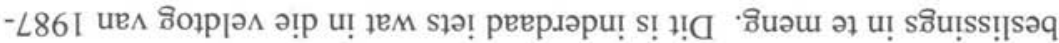

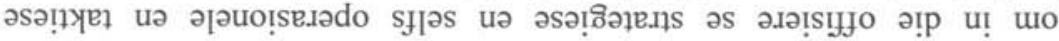

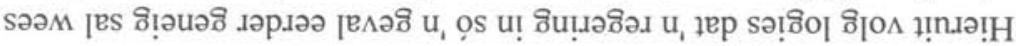

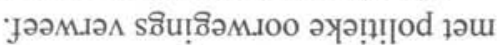

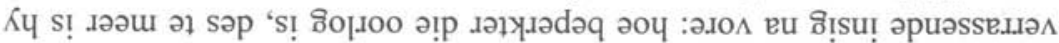

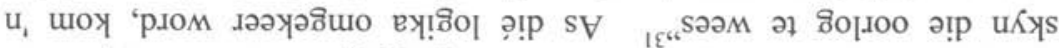

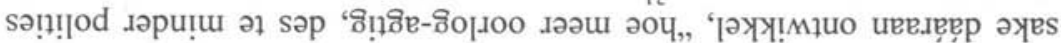

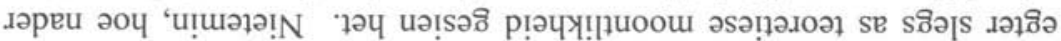

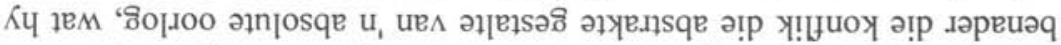

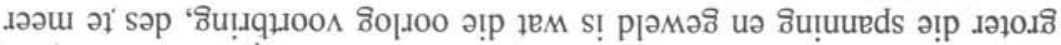

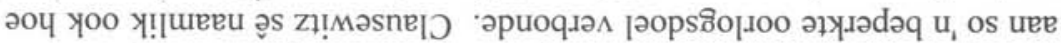

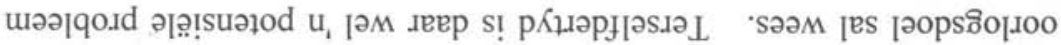

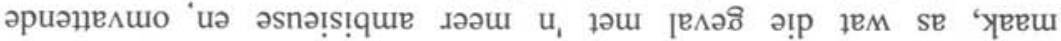

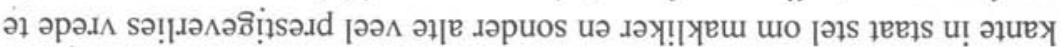

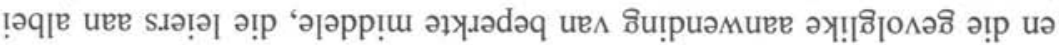

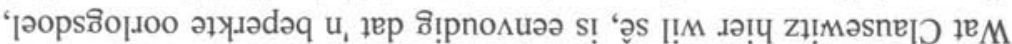

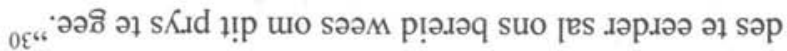

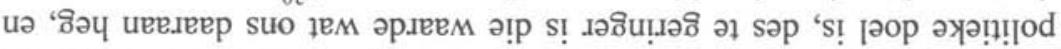

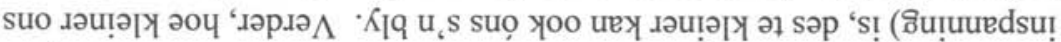

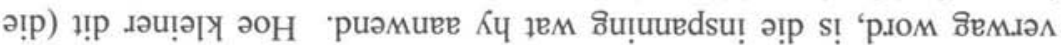

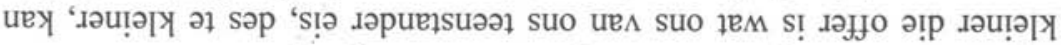

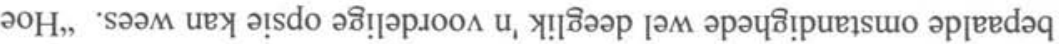

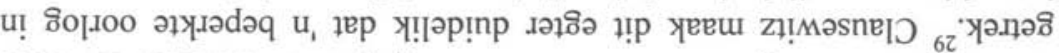

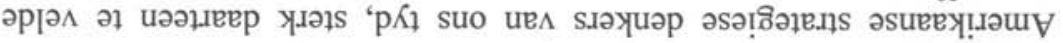

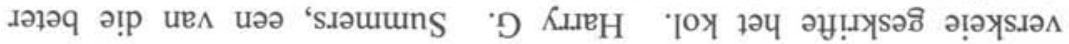

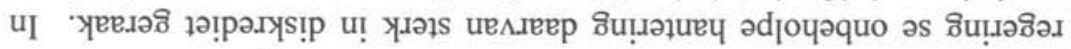

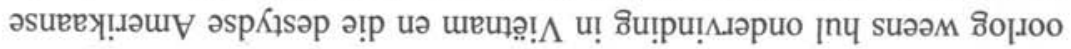

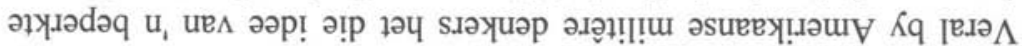

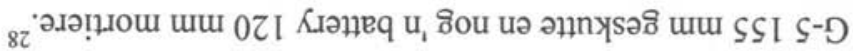

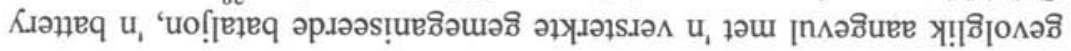




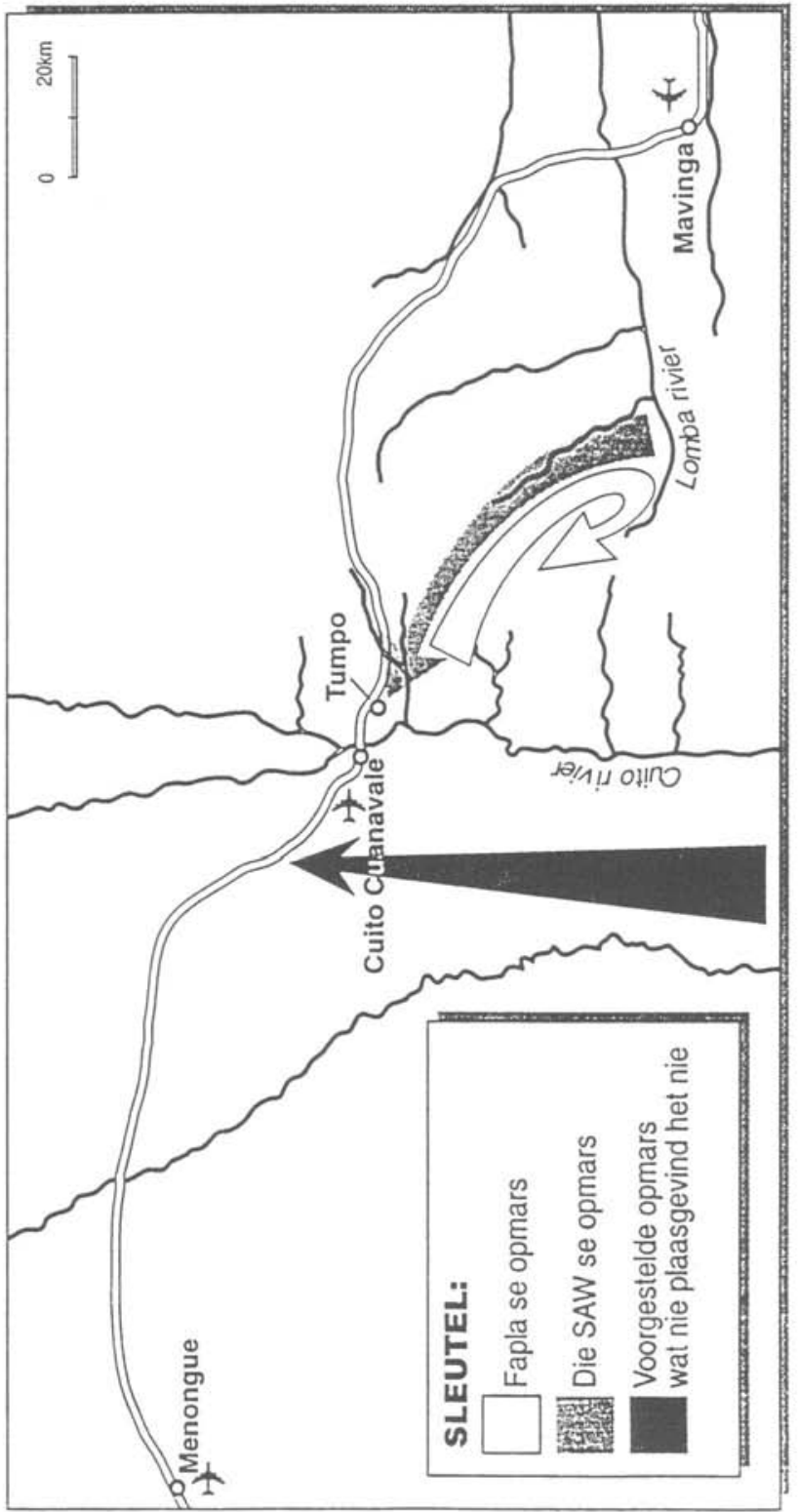

Heitman: War in Angola, pp. 30-31. 


\section{WES OF OOS VAN DIE CUITO?}

Uit Bridgeland se boek, wat hoofsaaklik op onderhoude met sommige van die deelnemende Suid-Afrikaanse offisiere gebaseer is, blyk dat daar aansienlike onmin was tussen - oorvereenvoudig gestel - die politici en generaals in Pretoria enersyds en die kolonels in die veld andersyds. Dit kom nie so eksplisiet na vore in Heitman se boek nie, maar bevestigende materiaal vir die voortdurende operasionele debatte is daar wel.

Blykbaar het die Hoof van Staf Operasies, It.-genl. Van Loggerenberg, al op 11 Junie 1987 'n eerste werkdokument uitgereik wat as grondslag vir die strategiese en operasionele debat moes dien. Volgens Heitman $^{33}$ is vier opsies voorgestel:

- slegs klandestiene hulp met min troepe, selfs al lei dit tot die val van Mavinga;

- 'n effens groter betrokkenheid, met aanvalle (ook lugaanvalle) op Fapla namate sy brigades opmarsjeer, maar operasies word beperk tot suid van die Chambingarivier, $30 \mathrm{~km}$ suid van Cuito Cuanavale;

- voldoende hulp om Mavinga te herower as die dorp sou val; en

- 'n groot betrokkenheid, wat begin met verrassingsaanvalle uit die lug op verskeie plekke in Suid-Angola, met inbegrip van die lugbasisse by Lubango en Menongue.

Die laaste opsie is as te gevaarlik en onmoontlik om geheim te hou verwerp. Op 15 Junie het die SAW op die eerste opsie en voorbereidings vir die tweede een besluit. Nadat die Kabinet dit goedgekeur het, is die formele operasionele instruksie vir Operasie Modulêr op 22 Junie uitgereik.

'n Ander beeld, wat nie noodwendig hierteen hoef in te druis nie, word deur Bridgeland ${ }^{34}$ gegee. Volgens hom het drie offisiere wat op voetsoolvlak in Namibië en Angola met die voorbereidings vir die naderende stryd besig was, kols. Jock Harris, Fred Oelschig en Piet Muller, nog voor die ontplooiing van die eerste Suid-Afrikaanse eenhede, 'n operasionele plan aan VHK voorgestel. "The favoured plan of the 
'three colonels' involved sending a major battle group from Namibia northwards along the western bank of the Cuito River, attacking Cuito Cuanavale from behind, and controlling the narrow road from Menongue along which logistics were being ferried to the (Fapla) brigades." Steun hiervoor het glo ook gekom vanuit Virginië in Amerika, waar die Kubaanse oorloper, lugmaggeneraal Rafael Del Pino Diaz, intensief deur die CIA ondervra is. Del Pino, wat tot kort tevore self in Angola geveg het, het laat weet dat die Suid-Afrikaners hulle op Fapla se toevoerroete tussen Menongue en Cuito Cuanavale moes konsentreer, nie op laasgenoemde dorp nie.

VHK het die plan na die Kabinet deurgestuur, waar dit verwerp is. Die motivering hiervoor, soos Bridgeland dit formuleer, was die volgende: "His (P.W. Botha se) fear, and that of his Cabinet, was of the international outcry that would follow if regular South African troops were perceived to be fighting several hundreds of kilometres inside Angola. For historical and strategical reasons it believed to be sound and just, Pretoria felt its involvement in the Angolan conflict was fully legitimate. But an attack towards Cuito Cuanavale from the west could not have been hidden and substantial casualties would have been inevitable ... Few countries would be disposed to understand the presence of a major South African military force in the territory of a sovereign black African state: instead, it would be used as another stick to beat a country trying desperately to re-establish international respectability."

Die Kabinet het gevolglik 'n ander plan goedgekeur: "A thrust into the area east of the Cuito River ... to prevent Fapla from capturing UNITA's strategical stronghold of Mavinga." Die ministers het voorts besluit dat die SAW se betrokkenheid geheim en sodanig beperk moes bly dat dit "plausibly deniable" sou wees. Die SAW se rol sou slegs defensief wees; nie offensief nie. Verder is 'n stel instruksies uitgevaardig wat hierop neergekom het: "No men must be lost; no equipment must be lost; and you must achieve all your objectives." ${ }^{35}$

Dié instruksies was klaarblyklik gemik op die geheimhouding van die operasie. In die lig van dié strewe is hulle op sigself begryplik, maar dit was militêre waansin. Die Kabinet het ' $n$ hele brigade beveel om ' $n$ 
taamlik omvattende operasie aan te pak, om Fapla se grootskaalse offensief te help stuit (wat onmoontlik sonder beduidende gevegte kon gebeur het), maar dit moes terselfdertyd sonder verliese van soldate en toerusting én met die bereiking van alle doelwitte gebeur! Dit was 'n onmoontlike opdrag en het nie van veel militêre insig getuig nie.

Hoe ook al, dis duidelik dat die Regering in dié stadium geensins aan 'n Angolese veldtog, soos dit later ontwikkel het, gedink het nie. Inteendeel, die idee was eerder min of meer 'n herhaling van die beperkte operasie van 1985, wat ondanks internasionale vermoedens tot die teendeel tog "plausibly deniable" gebly het. Dis dan ook op sigself waar dat die uitvoering van die kolonels se plan in dié stadium die uiters beperkte oorlogsdoel - om Fapla se aanval af te slaan sonder dat die SuidAfrikaanse betrokkenheid bekend word (dink weer aan die debakel van 1975-'76!) - sou verongeluk het.

Agterna betrag, was dit natuurlik 'n naïewe verwagting, veral toe dit duidelik word dat 'n herhaling van die gebeure van 1985 nie moontlik was nie en dat die Suid-Afrikaanse betrokkenheid minstens op brigadevlak sou wees. Om 'n klein troepemag soos dié van 1985 geheim te hou, kon gedoen word. Om 'n hele brigade geheim te hou, was volkome buite die kwessie.

Soos verwag kon word, het die aanwesigheid van Suid-Afrikaanse soldate dan ook betreklik gou uitgelek. Teen einde November het die nuus in Britse en Amerikaanse koerante uitgeslaan, waarvandaan dit gou sy weg na die Suid-Afrikaanse media gevind het. ${ }^{36}$ Op 13 November moes die Minister van Verdediging, genl. Magnus Malan, die betrokkenheid van Suid-Afrikaanse magte by die gevegte toegee. ${ }^{37}$

Soos verstaan kon word, het die koerante onmiddellik in die openbaar begin vra presies wat aan die gang was. Die voorbeeld van 1975-'76, toe lede van die Regering in die Volksraad ontken het dat Suid-Afrikaanse soldate in Angola by gevegte betrokke was - 'n flagrante leuen - het steeds gespook. "Dit maak nie sin dat buitelandse nuusmedia deur middel van vreemde nuusagentskappe oorsee publisiteit gee aan ons betrokkenheid in Angola, terwyl die mense vir wie dit die belangrikste is 
- die ouers van die seuns wat daar veg en die publiek wat dít finansier en moreel steun - nie bevredigend deur hul eie plaaslike nuusmedia ingelig kan word nie," het Die Burger in 'n hoofartikel geskryf. ${ }^{38}$

En die Cape Times: "If South African land or air forces have been committed across our borders in somebody else's civil war the South African taxpayers are entitled to be told what is going on - and how the use of costly resources of men and material can be justified in the national interest ... The secrecy of the SADF in this instance is unacceptable in a country which maintains a citizen army. How can you get the support of the people for a war on foreign soil if you do not even tell the people what you are doing and why you are doing it?"39

Dié standpunt het met meer as slegs openbare belang en deursigtigheid te make. Clausewitz het al gewys op die "merkwaardige drie-eenheid" van regering, weermag en volk: nie alleen verleen die volk die soldate waarmee geveg moet word nie; die passie wat uit die oorlog voortkom, moet reeds in die volk aanwesig wees. ${ }^{40}$

J.S. Kotzé skryf in dié verband tereg: "Die openbare mening" - en dit geld natuurlik des te meer vir moderne, oop samelewings - "is bepalend vir die intensiteit waarmee nasionale belange beskerm moet word én die koste en die risiko's wat in dié verband aangegaan kan word. Militêre operasies wat nie openbare steun geniet nie, het dikwels rampspoedige politieke gevolge vir die regering en veroorsaak 'n groot verleentheid vir die gewapende magte." ${ }^{41}$

Die samestelling van 20 SA Brigade was deels dienspligtiges burgers in uniform. Tog het die Regering nie alleen nagelaat om die openbare mening te mobiliseer nie; hy wou 'n beduidende operasie geheim hou, en dit terwyl elkeen wat iets van publisiteit begryp, hom vantevore kon ingelig het dat die uitlek daarvan heeltemal onafwendbaar was. Dit was 'n flater van die eerste orde, soortgelyk aan dié van die Amerikaanse regering wat geweier het om sy kiesers se steun vir die oorlog in Viëtnam te mobiliseer. ${ }^{42}$ Op sy minste moes die Regering, toe

Ibid., 2.10.1987.

Cape Times, 29.9.1987.

Clausewitz: On War, I/1, p. 26.

Kotzé: "Die Strategiese Kontinuum" (Joernaal vir Eietydse Geskiedenis, 19/3, Des. 1994, pp. 44-45.)

Vgl. Hieroor Summers: On Strategy II, pp. 7-19. 
sy betrokkenheid uitgelek het, 'n groot propaganda-offensief van stapel gestuur het. Dit sou dit ook vir Kuba moeiliker gemaak het om so 'n enorme propaganda-oorwinning insake die Suid-Afrikaanse "nederlaag" by Cuito Cuanavale te behaal. Maar propaganda en openbare kommunikasie was van oudsher 'n Achilles-hiel van die destydse Regering en SAW.

Die gevolgtrekking uit dit alles is duidelik. Die primêre rede vir die weiering van die politici om die kolonels se plan uit te voer was wel begryplik, maar het van grenslose naïwiteit oor die werklike lewe getuig - en was dus ongeldig. Dus is ' $n$ direkte benadering aan die troepe in die veld opgedwing: hulle moes Fapla aangryp waar hy die sterkste was en dit verwag het, pleks van om hom te omvleuel en hom op sy gevoeligste plek in sy agtergebiede te bedreig waar hy dit nie verwag het nie. Dit het teen alle beginsels van oorlogvoering ingedruis. As die besluitnemers 'n behoorlike begrip van die teoretiese beginsels van die strategie en operasionele kuns gehad het, wie weet, kon sake anders verloop het ...

\section{DIE OPERASIONELE DOEL WORD GEWYSIG}

Saam met soldate van Unita het 20 SA Brigade einde September en begin Oktober 1987 'n reeks gevegte aan die Lomba gevoer. Fapla het die rivier telkens op dieselfde plek en op dieselfde manier probeer oorsteek en is telkens met groot verliese teruggedryf. Die klimaks hiervan was 'n groot geveg op 3 Oktober toe die Suid-Afrikaanse gemeganiseerde infanterie waarskynlik die skitterendste taktiese oorwinning in die geskiedenis van die SAW sedert 1945 behaal het. Teen die einde van sy mislukte offensief was Fapla heeltemal gedemoraliseer en verslaan. Een brigade is feitlik heeltemal vernietig; die ander het moedeloos, terneergedruk en met die agterlating van baie swaar wapentoerusting noordwaarts teruggetrek.

Dié oorwinnings het die hele operasionele en strategiese situasie gewysig. Kol. Deon Ferreira, bevelvoerder van 20 SA Brigade, se boodskap aan genl. Willie Meyer, bevelvoerder van die Kommandement Suidwes-Afrika, was daarom iets in dié trant: "My mission has been 
accomplished. We have stopped the advance to Mavinga. They (Fapla) are redeploying north and then west." ${ }^{43}$

Geldenhuys was dit daarmee eens. "Vanaf hierdie punt was daar vir my net een oorweging: Ons het reeds ons missie voltooi. Ons het die vyandelike offensief totaal uitmekaar geslaan." ${ }^{44}$

Ferreira en Geldenhuys had gelyk. Die Suid-Afrikaanse strategiese doel, soos deur die Kabinet bepaal, was om Unita as faktor te laat oorleef deur Fapla se offensief af te slaan, en dit is bereik. Met die noordwaartse terugtrekking van die Angolese magte het dit dus nodig geword om die strategiese en operasionele situasie opnuut te bekyk.

Die krygsgeskiedenis getuig daarvan dat 'n suksesvolle verdediging slegs in uitsonderlike gevalle ' $n$ beslissing in 'n oorlog kan afdwing. Meestal is ' $n$ offensief daarvoor nodig. Ofskoon Clausewitz die verdediging in abstrakte sin as sterker as die offensief beskou, noem hy eersgenoemde tog 'n "negatiewe element" wat uit swakheid spruit. Hieruit volg dat "ons net daarvan gebruik moet maak solank ons swakheid ons daartoe dwing, en dat ons dié vorm moet prysgee so gou as ons sterk genoeg is om die positiewe doel (d.i. die offensief) voort te sit." 45

Iets soortgelyks het vir die gekombineerde Suid-Afrikaanse en Unitamagte gegeld. Al het die strategie in beginsel verdedigend gebly - die oorlogsdoel is geensins gewysig nie - moes die operasionele postuur offensief word om die voordele wat reeds behaal is te konsolideer. "Ons kon egter nie vir ewig die voordele wat behaal is, self in stand hou nie," skryf Geldenhuys. "Oor die langer termyn gesien moes ons die gebied so agterlaat dat, indien daar in die toekoms weer 'n 'jaarlikse' offensief uitgevoer word, Unita dit sonder ons hulp sou kon afslaan. Dit is wat ons wou bereik. Niks meer nie, en niks minder nie." ${ }^{46}$

Selfs nog voor die finale oorwinning aan die Lomba het 20 SA Brigade in die nag van 28 op 29 September besoek ontvang van pres. P.W. Botha, genl. Magnus Malan en mnr. Wynand Breytenbach (Minister van Verdediging en sy Adjunk), genl. Jannie Geldenhuys (Hoof van die Weermag), lt.genl. Kat Liebenberg (Hoof van die Leër) en enkele ander

Bridgeland: The War for Africa, p, 164.

Geldenhuys: Dié wat wen, p. 172.

Clausewitz: On War, V1/1, pp. 135-136. 
generaals. Hulle is ingelig oor die operasionele situasie, asook dat daar selfs ná die finale mislukking van die Fapla-offensief nog groot vyandelike magte oos van die Cuito sou wees. Om 'n taktiese oorwinning aan die Lomba te konsolideer moes gevolglik tot die offensief oorgegaan word om Fapla uit die gebied oos van die rivier te verdryf. Heitman sê Botha "made it clear that the defeat should be so crushing, that Fapla would not be able to launch a new offensive in 1988."47

Omdat 20 SA Brigade egter ad hoc saamgestel was om 'n verdedigende doel te dien, moes bykomende magte uit Suid-Afrika aangevoer word. Die belangrikste daarvan was 'n eskadron Olifant-tenks, asook ekstra artillerie en infanterie. Dit het die Suid-Afrikaanse sterkte op nagenoeg 3000 man te staan gebring. Omdat daar eers vir dié magte gewag moes word, kon die Suid-Afrikaners ewenwel nie die lewensnoodsaaklike operasionele beginsel nakom om 'n verslane vyand te agtervolg nie. Dit het beteken dat Fapla in die volgende maand taamlik kon herstel.

Teenoor sy offisiere het genl. Geldenhuys die praktiese operasionele riglyne, gebaseer op Botha se politieke opdrag, só gestel: 'n SAWonttrekking uit Angola moet só geskied dat dit Fapla nie bevoordeel nie; die vordering wat in die operasie gemaak is, mag nie prysgegee word nie; en die SAW kan hom slegs onttrek wanneer Fapla na die westekant van die Cuito verdryf is, die rivier self as verdedigingslinie voorberei is, en Unita sy eie verdediging kon oorneem. ${ }^{48} \mathrm{Nie}$ almal het ewenwel hiermee saamgestem nie.

\section{WEER EENS: WES OF OOS VAN DIE CUITO?}

In die weke en maande wat op die Lomba-gevegte gevolge het, het die operasionele debat weer eens opgevlam: langs welke roete moes die swaartepunt van die komende offensief wees, wes of oos van die Cuito? Anders gestel: moes die vyand met regstreekse aanvalle tot oor die rivier teruggedryf word, of moes hy deur 'n groot omvleuelingsbeweging aan 
die westekant van die rivier van sy logistieke hinterland afgesny word sodat hy vanself sou kwyn en sterf?

Op 16 Oktober het die HK van 20 SA Brigade albei opsies aan genl. Liebenberg voorgehou. Die generaal was nogal vir die westelike opsie te vinde, en het selfs opdrag gegee dat moontlike punte om die Cuito weswaarts oor te steek ondersoek word, maar geen finale beslissing geneem nie. Die saak is op 18 November weer tussen Geldenhuys en Liebenberg bespreek, maar weer eens is geen besluit geneem nie. ${ }^{49}$

Een van die Suid-Afrikaanse offisiere, kmdt. (tans kol.) Robbie Hartslief, het aan Bridgeland vertel dat daar groot frustrasie by hom en sy kollegas oor die saak was. "All the combat commanders wanted to launch an attack from the west as early as November 1987. Even in December we could have attacked the Menongue-Cuito Cuanavale road in strength and cut all their logistics. The war would have been over. The enemy couldn't have stayed there (in Cuito Cuanavale)."

Die besluit van die Regering was egter anders, en weer eens het politieke oorwegings die deurslag gegee.

Volgens Chester Crocker het pres. Fidel Castro reeds op 27 Julie, selfs voordat die Fapla-offensief behoorlik aan die gang gekom het, 'n mondelinge boodskap aan die Amerikaanse regering gestuur. Daarin het hy - klaarblyklik sonder om die Sowjets of die MPLA te raadpleeg voorgestel dat sy land by die langdurige vredesamsprekinge tussen die Amerikaners en die MPLA betrek word. Crocker sê ten spyte van die manhaftige toon van die boodskap, "one could infer that Cuba was interested in winding down its Angolan entanglement". 51

Dit is inderdaad duidelik dat Fapla sy offensief oorspronklik op aanbeveling van die Sowjets, en téén die advies van die Kubane, begin het; vandaar dat die Kubaanse troepe in Angola aanvanklik glad geen rol in die gevegte gespeel het nie. In 'n toespraak in 1988 het Castro in 'n nouliks verhulde aanval op die Sowjets en die MPLA gesê dat die geskiedenis sou vertel watse foute begaan is. "Ek gaan net sê dat Kuba nie vir daardie foute verantwoordelik was nie." ${ }^{, 2}$ In 'n ander toespraak 'n jaar later het hy herhaal dat "ons op geen wyse verantwoordelik was vir

Ibid., pp. 93 en 156.

Bridgeland: The War for Africa, p. 292.

Crocker: High Noon in Southern Africa, p. 355. 
die foute wat tot daardie situasie (Fapla se nederlaag aan die Lomba) gelei het nie ..."

In hierdie tyd - dit is nie bekend presies wanneer nie, waarskynlik êrens in Oktober of November - het Kubaanse diplomate ook in verbinding getree met die Suid-Afrikaanse ambassade by die VN in New York. Die doel daarvan, soos Bridgeland dit formuleer, was "to explore the possibility of a negotiated settlement of the Angolan conflict. Such an agreement, Castro suggested, could be linked to a resolution of the problem in the neighbouring South African-ruled Namibia." Aangesien dit presies die "linkage" tussen die uitvoering van Resolusie 435 (oor die onafhanklikwording van Namibië) en die onttrekking van die Kubane aan Angola was waarvoor die Regering hom al jare lank beywer het, het die Suid-Afrikaners uiteraard hul ore gespits. "From now onwards the foreign affairs mandarins would have an ever greater input into the conduct of the War for Africa," skryf Bridgeland. ${ }^{54}$

In sulke omstandighede wou die politici dus nie 'n operasie wes van die Cuito toestaan wat Fapla se leiding sodanig sou verneder dat hy minder tot 'n ooreenkoms geneig sou wees nie. Die "macho-faktor" by die vyand het ' $n$ al hoe groter rol by die Suid-Afrikaners se besluitneming begin speel. Die versoek om in 'n groot flankbeweging wes van die rivier op te trek en Fapla van dié kant af te sny is gevolglik verwerp. Die alternatiewe opdrag was om 'n sodanige bedreiging teen die vyand oos van die Cuito te vorm dat hy self weswaarts oor die rivier sou retireer. ${ }^{55}$

\section{BEOORDELING VAN DIE OPERASIONELE PLAN}

Sonder om verder op die saak in te gaan, skryf genl. Geldenhuys, klaarblyklik oor die strategiese en operasionele debat in die SAW: "Ek bevraagteken sommige skrywers se uitgangspunte. As hulle die taktiese verloop van operasies nie wil baseer op vertolkings van generaals ver weg nie, moet hulle ook nie die strategiese oorwegings van 'n kampanje

Die Burger, 29.7.1988.

Aangehaal in Steenkamp: South Africa's Border War, p, 255.

Bridgeland: The War for Africa, p. 228.

lbid., pp. 227-229; Heitman: War in Angola, pp. 157-158. 
probeer ontleed op grond van die sienings van die vegters in die bos ver weg van die strategiese wêreld af nie." ${ }^{56}$

Daarteenoor staan dié aanhaling uit Bridgeland: "Time and again, as this book was researched, these officers ... asked the author to switch off his tape recorder while they gave him their off-the-record opinions of what they had been asked to do. 'Fundamentally stupid,' said one highly decorated officer ..." 57

Dit is inderdaad geen duidelike saak nie; daar is heelwat vir albei kante te sê. Ons het tot dusver gesien dat oorlog primêr 'n politieke handeling is en dat alle krygshandelinge dus met inbegrip van politieke oorwegings beoordeel moet word. Omdat die politiek die intelligensie en die oorlog slegs die instrument is, geld egter die primaatskap van die politiek.

Dit beteken nie dat die politici 'n vrybrief het om na willekeur in die operasionele sfeer, die sfeer van die militêr, in te meng nie. Hulle kan dit slegs doen as hulle daarvan oortuig is dat die operasionele planne of handelinge teen die verklaarde oorlogsdoel indruis. Liddell Hart sê 'n regering "should not interfere with him (the commander) in the handling of his tools ...", en "policy should not demand what is militarily - that is, practically - impossible" ${ }^{58}$ Ook Clausewitz sinspeel daarop wanneer hy skryf dat as die politiek eise aan die oorlog stel waaraan laasgenoemde nie kan voldoen nie, "sal dit indruis teen die aanname dat hy (die politiek) die instrument ken wat hy gaan gebruik ..." In só 'n geval, sê hy, is die politiek fout. ${ }^{59}$

In die Viëtnamese Oorlog het die administrasie van pres. Lyndon B. Johnson dié reël gereeld met oorgawe - en verwoestende gevolge oortree. In die Wit Huis is byvoorbeeld teikens vir lugaanvalle bepaal, en selfs die taktiek wat by sulke aanvalle gevolg moes word, is deur die Wit Huis neergelê. Geen wonder dat die Amerikaanse weermag byna 'n trauma oor die saak ontwikkel het nie. Daarom dat die Amerikaanse strategiese denker kol. Harry Summers vir pres. George Bush so uitbundig prys omdat dié slegs die politieke doel van die Golfoorlog van

Geldenhuys: Dié wat wen, p. 223.

Bridgeland: The War for Africa, p. 230.

Liddell Hart: Strategy, pp. 334 en 351.

Clausewitz: On War, VIII/6, pp. 125 en 126. 
1990-'91 neergelê en die militêre owerhede daarna gelos het om hul taak uit te voer. ${ }^{60}$

In die geval van die Angolese veldtog, so lyk dit, het die SuidAfrikaanse politici - of was dit dalk die generaals wat die politieke parameters te streng vertolk het? - oortree. Ons het reeds gesien dat die strategiese doel was om Unita te laat oorleef. Om dit reg te kry, so het die politici aanvanklik verordineer, moes Fapla se opmars na Mavinga gestuit word. En toe dit reggekry is, is die operasionele opdrag deur pres. Botha self uitgebrei om die vyand só hard te slaan dat hy die res van 1987 en die hele 1988 nie weer in staat sou wees om weer so 'n offensief van stapel te laat loop nie. Binne dié politieke parameters moes die bevelvoerders op voetsoolvlak toegelaat gewees het om self hul operasionele planne op te stel.

Die politici en diplomate het tereg die potensieel negatiewe uitwerking van 'n offensief wes van die Cuito op die ontwikkelende vredesinisiatiewe in aanmerking geneem. Maar sou só 'n opmars inderdaad die vredesbelofte gesmoor het?

Hul oordeel was ja. Maar dit het beteken dat hulle die offisiere in Angola met onmoontlike en teenstrydige beperkings opgesaal het: enersyds het hulle die troepe bevéél om Fapla só hard te slaan dat hy minstens die volgende vyftien, sestien maande gebreek sou wees; andersyds is die troepe verbiéd om Fapla só hard te slaan dat dit die vredesinisiatiewe kon verongeluk. Dit was eenvoudig absurd, en die bitterheid van die kolonels en kommandante op voetsoolvlak in Angola was geen wonder nie.

Dié paradoks het uiteindelik in die praktyk in 'n klassieke kompromis neerslag gevind, 'n geval waar die soldate gedwing is om op twee stoele te sit en dus in die middel deurgeval het. Want enersyds moes hulle wél voortgaan om Fapla hárd te slaan, maar andersyds mog hulle dit nie op die mees voordelige wyse doen nie. Inteendeel, van hulle is verwag om dit op 'n wyse te doen wat alle gesonde strategiese, operasionele en taktiese beginsels, soos hierbo uiteengesit is, verkrag het.

Dit het naamlik in die praktyk beteken dat 20 SA Brigade en Unita ' $n$ reeks harde frontaanvalle teen die terugtrekkende Fapla moes doen. Die 
hoop dat Fapla deur 'n dreigende postuur vanself op die vlug sou slaan, het naïef geblyk. Van 'n operasionele omvleuelingsbeweging om die vyand aan te tas waar hy op sy swakste was en dit nie verwag het nie; van enige poging om die vyand te ontwrig en sy moontlike weerstand te verminder vóórdat hy eventueel in gevegte aangepak word - daarvan was daar nie die minste sprake nie. Om van die hoogste ideaal, die strewe om die vyand sónder enige geveg te oorwin, nie eens te praat nie!

Selfs Clausewitz, wie se denke oor operasionele sake soms ietwat verouderd is, ag verrassing 'n hoë doel om na te streef: "Dit lê aan die basis van alle handelinge, want daarsonder is die oorwig op die beslissende punt nie werklik denkbaar nie ... Wanneer dit op groot skaal bereik word, verwar dit die vyand en verlaag sy moreel; baie voorbeelde, groot en klein, wys hoe dit die resultaat op sy beurt vermenigvuldig., ${ }^{61}$ Clausewitz het dit dus al in die moderne jargon as magsvermenigvuldiger beskou.

Gevolglik moes die Suid-Afrikaners en hul Unita-bondgenote frontaanval ná frontaanval doen en vind dat Fapla telkens ietwat seergemaak, maar steeds intak, teruggedryf word. Ten slotte moes hulle nie minder nie as drie frontaanvalle op ' $n$ uitstekend ingegrawe vyand by Tumpo, reg oorkant Cuito Cuanavale aan die oostekant van die Cuito, doen.

Dié gebied word aan drie kante deur riviere begrens, waardeur die maneuvreerruimte van die aanvaller aansienlik beperk word. Bowendien, soos Heitman dit stel: "The situation around Tumpo heavily favoured Fapla. Not only was the terrain favourable to the defence, but they had several months to dig in and prepare it. They had built strong positions strengthened with minefields, with fields of fire cleared where necessary by bulldozers. Infantry supported by tanks, anti-tank weapons and artillery were positioned to cover all approaches to the base, a thorough network of defensive fire tasks in support of these defences. The guns and rocket launchers had been carefully emplaced singly or in pairs, with multiple surveyed alternative firing postions. That enabled them to evade counter-battery fire without becoming ineffective in the process. Large 
amounts of ammunition and other stores had been stockpiled in the positions and west of the Cuito. ${ }^{62}$

Teen die einde van sy lewe het Liddell Hart die kern van sy operasionele denke in twee punte opgesom: "The first is that ... no general is justified in launching his troops to a direct attack upon an enemy firmly in position. The second, that instead of seeking to upset the enemy's equilibrium by one's attack, it must be upset before a real attack is, or can be, successfully launched ...,63

'n Opmars wes van die Cuito sou by uitnemendheid aan Liddell Hart se voorskrifte voldoen het. Om mee te begin was die Fapla-magte hoofsaaklik oos van die rivier gekonsentreer; wes daarvan was slegs logistieke eenhede rondom Cuito Cuanavale en Menongue. Die hele strook tussen die Namibiese grens en Cuito Cuanavale wes van die Cuito was verlate. 'n Opmars hier sou dus die vyand fisiek en psigologies heeltemal onkant betrap het. Die Fapla-magte oos van die Cuito sou daardeur van hul steunbasis aan die westekant afgesny word en waarskynlik vanself weggekwyn het. Só sou Fapla se weerstandsvermoë dan ondermyn word; sou hy ontwrig word nog voor 'n geveg kon plaasvind; sou hy dalk selfs sónder 'n geveg oorwin kon word.

Bowendien, hoe verder noord Fapla teruggedryf is, hoe korter het sy logistieke aanvoerroetes en hoe langer het dié van Suid-Afrika geword. Daardeur is Fapla bevoordeel en Suid-Afrika benadeel. By 'n opmars wes van die Cuito sou dit natuurlik ook vir Suid-Afrika gegeld het, maar dit sou wel gepaard gegaan het met die totale ontwrigting van die vyand, iets wat ruimskoots vir die logistieke probleme sou vergoed het.

Dis nietemin waar dat 'n flankbeweging wes van die Cuito in dié stadium moeiliker as aan die begin van die veldtog sou wees en dat die verrassingselement ook nie heeltemal so groot sou wees nie. Aan die begin van die veldtog sou die Suid-Afrikaanse troepe van meet af aan wes van die Cuito kon opgeruk het; in die tweede fase sou hulle die Cuito van oos na wes moes oorgesteek het. Daar is geen manier hoe die SuidAfrikaners en Unita só 'n beweging geheim sou kon hou nie. Fapla was waarskynlik nie buigsaam genoeg om dadelik sy magte by Tumpo oor die 
rivier terug te trek nie, maar die beweging sou noodwendig die aandag van die Angolese lugmag getrek het.

Nietemin het die Angolese vliegtuie hul lugaanvalle deels uit vrees vir Unita se draagbare Stinger-lugafweermissiele op die groot hoogte van 6 000-16 000 voet gedoen, wat beteken het dat hul akkuraatheid maar baie power was. ${ }^{64}$ Bowendien, die offisiere ter plaatse het daarvoor kans gesien en hul mening moet noodwendig groot gewig dra.

Dis nie ongeregverdig om aan te neem dat die Suid-Afrikaanse oorsteek van die Cuito met aansienlike probleme gepaard sou gegaan het nie, maar dis baie waarskynlik dat hulle dit beslis sou kon reggekry het, al moes dit dan in die nag geskied. Van daar kon hulle dan vinnig noordwaarts aangemars en Cuito Cuanavale van Menongue afgesny het. Die kans is goed dat die Fapla-magte sonder alte veel van 'n geveg sou gedesintegreer het.

Sou dit die vredesinisiatiewe gekelder het? Enige antwoord moet slegs op gissings berus. Tog, dis moeilik om in te sien dat indien die drie skerp frontaanvalle op Tumpo waartoe 20 SA Brigade uiteindelik teen sy sin gedwing is die vrede nié beduiwel het nie, 'n flankbeweging wes van die Cuito dit wél sou gedoen het. Botha se strategiese opdrag dat Fapla sodanig geslaan moet word dat hy nie weer voor einde 1988 tot 'n offensief in staat sou wees nie, is immers deur niemand beskou as ' $n$ gevaar vir die beginnende vredesproses nie. Hoe kon die beste moontlike uitvoering daarvan dan so gesien word?

Maar die kolonels en kommandante het nie hul sin gekry nie. Soos verwag kon word, het al drie sinlose frontaanvalle by Tumpo misluk en het veral Unita se infanterie swaar verliese gely. By die derde aanval moes die Suid-Afrikaners selfs drie Olifant-tenks agterlaat. Fapla het dus 'n bruggehoof oos van die Cuito behou, wat beteken het dat die SuidAfrikaanse operasionele doel nie heeltemal bereik kon word nie. Dit was dié reeks mislukkings wat Fidel Castro die kans gegee het om oor die swaar Suid-Afrikaanse "nederlaag" by Cuito Cuanavale te kraai.

Hoe ook al, dié beslissing sal waarskynlik in die toekoms 'n taamlike debatspunt tussen krygshistorici word, want dit is geen saak waar 'n 
wiskundig sekere antwoord geld nie. Daar is goeie argumente na weerskante.

Ewenwel, uiteindelik het die generaals 'n beperkte, klandestiene operasie deur 32 Bataljon wes van die Cuito goedgekeur om Fapla se aanvoerroete tussen Menongue en Cuito Cuanavale af te sny. Net soos aan die begin van die veldtog was die beperkings weer onmoontlik streng: verloor geen menselewens nie, verloor geen toerusting nie en bereik al die doelwitte - wat weer eens absurd was. Aan eersgenoemde twee is, danksy enorme inspannings, voldoen; aan laasgenoemde kon weens die beperkte middele wat aan die operasie toebedeel is, slegs gedeeltelik voldoen word. ${ }^{65}$ 'n Behoorlike alternatief vir 'n volskaalse opmars hier was dit beslis nie.

\section{CASTRO SE MEESTERSKUIF}

Ondanks bogenoemde fout het sake in strategiese opsig in die eerste maande van 1988 nie alte sleg vir die Suid-Afrikaners gelyk nie. Fapla is ver teruggedryf, van die Lomba tot by Tumpo, en hy kon hier slegs ' $n$ bruggehoof handhaaf.

Die oorspronklike oorlogsdoel, soos hierbo beskryf is, was bloot om Unita te help oorleef. Fidel Castro se kennisgewing dat hy tot die onderhandelingsproses insake Angola en Namibië wil toetree, het die strategiese situasie daarom dramaties verander. Vir die eerste keer, so het dit gelyk, was daar die moontlikheid van 'n situasie wat tot die onttrekking van die Kubane kon lei.

Castro was dit nie eens met Fapla se offensief teen Unita nie; dit was die inisiatief van die konserwatiewe vleuel in die Kremlin. Daarom het sy magte in Angola volgens Chester Crocker "a distinctly secondary role" in die gevegte gespeel. "Cubans manned the Lubango-Menongue defence lines well to the northwest of Cuito Cuanavale, supported the FAPLA logistic effort, flew air sorties, and provided the garrison strength that freed up FAPLA units for battle. But the government in Havana disagreed with the Soviet plan and had done little to advance it. By 
November, it was fair to say that the Cubans had a lead role in neither the diplomacy nor the war." 66

Ter agtergrond moet in ag geneem word dat die oorlog in Angola onder die Kubaanse bevolking ongewild geword het, amper soos die Viëtnamese Oorlog destyds onder die Amerikaners. In teenstelling tot die Amerikaners kon die Kubane hul ontevredenheid natuurlik nie openlik lug nie.

Die Kubaanse generaal Rafael del Pino Diaz, wat vlak voor die Angolese veldtog na Amerika uitgewyk het, het in sy veilige huis in ' $n$ reeks gesprekke aan Fred Bridgeland vertel dat die Kubane aanvanklik, in die jare sewentig, besonder entoesiasties oor en trots op hul land se rol in Angola was. Maar Castro - en sy landgenote - het nie verwag dat Unita 'n uitgerekte guerrilla-veldtog volgens die klassieke model van Mao Zedong sou begin nie, en allengs het die geesdrif begin kwyn. Angola het Kuba se Viëtnam geword. "Only Fidel and his brother Raoul had any faith in victory." ${ }^{67}$

In sy boek noem Crocker vier faktore wat Castro se houding teen dié tyd bepaal het:

- die oorlog was ongewild in Kuba, en daar was aansienlike vrees dat die terugkerende troepe vigs op die eiland kon versprei;

- Kuba se ekonomie was in 'n haglike toestand. En Angola kon nie meer in harde valuta vir Kuba se bydrae tot die konflik betaal nie;

- Castro en sy raadgewers het 'n grondige minagting vir die SowjetUnie en Fapla se verbeeldinglose strategie in die oorlog gehad. Hulle was trouens teen die offensief van 1987 gekant en het daarom feitlik geen rol daarin gespeel nie; en

- Castro se felle trots oor die rol van sy land in die internasionale politiek wat gebaseer was "on the fierce pride of a small state whose leader had a grandiose sense of destiny". As hy dus uit Angola moes padgee, sou dit moes gebeur met behoud van sy eer. ${ }^{68}$

Castro het gevolglik 'n strategiese plan met twee komponente ontwerp. Die eerste was vrede; die tweede oorlogsdreigemente. In die eerste plek het hy dus, toe die Amerikaners as bemiddelaars daarin geslaag het om 'n 
sekere momentum aan die vredesonderhandelinge te verleen, sy land as sleutelspeler op die podium gevestig, 'n speler sonder wie die spel geen sin had nie.

Uit die Suid-Afrikaanse oogpunt was dit 'n uiters interessante ontwikkeling wat trouens gelei het tot ' $n$ uitbreiding van die oorlogsdoel. Waar dit vroeër eenvoudig was om Unita te help oorleef, het nou 'n tweede doel bygekom: om die Kubane uit Angola te kry en 'n omvattende vredesooreenkoms vir sowel Angola as Namibië te bereik. Vir die SuidAfrikaners was dit 'n belangrike potensiële deurbraak; vandaar die begryplike, maar dalk misplaaste politieke inmenging in die operasionele beplanning van die oorlog.

Die tweede komponent van Castro se strategie was, populêr gestel, om "chicken" met die Suid-Afrikaners te speel. Oor dié aspek is slegs een bron bekend, 'n toespraak wat hy in Julie 1989 in Havana gehou het en wat 'n merkwaardig eerlike uiteensetting van die gebeure bevat.

Castro het gesê Fapla se nederlae het die gevaar bevat dat "die konsentrasie Angolese troepe by Cuito Cuanavale uitgewis kon word". Ofskoon "ons geensins verantwoordelik was vir die foute wat tot daardie situasie gelei het nie" - 'n klap na Moskou en Luanda - "kon ons nie stilsit en 'n militêre en politieke katastrofe toelaat nie". Gevolglik is Kubaanse versterkings na Angola gestuur, en die eerstes het reeds op 15 November aangekom. Dit sou uiteindelik die hele 50ste Kubaanse Divisie, 'n gemeganiseerde mag van 15000 man, omvat.

Castro het vertel dat hy teen middel Desember 1987 verneem het dat die Fapla-hoofkwartier in Luanda ingestem het tot 'n algemene terugtog uit Cuito Cuanavale en Menongue noordwaarts na die Benguela-spoorlyn, 'n voorstel wat hy onmiddellik verwerp het. Om die situasie by Tumpo te stabiliseer het hy gevolglik 'n pantsereskadron en artillerie na die toneel gestuur en die MPLA meegedeel dat sy Kubane die operasionele bevel aan die front sou oorneem. Op 10 Maart het hy 50 Divisie opdrag gegee om suidwaarts na die Namibiese grens op te ruk: "Die belangrikste van al die strategiese operasies het begin." ${ }^{69}$

Wat hier veral belangrik is, is dat die opmars na die grens nie in die operasionele gebied in Suidoos-Angola plaasgevind het nie, maar in die 
gebied noord van Ovambo en die Kaokoveld, 'n hele stuk weswaarts dus. Teen einde Mei was die troepe goed ingegrawe en is selfs die landingstroke by Xangongo en Cahama sodanig verleng dat hulle MiG23 's kon huisves.

Dit was sonder meer 'n strategiese meesterskuif. Soos Crocker dit stel: "It would be the grand strategist's classic 'flanking maneuver': a dramatic drang nach südwesten to pry the SADF out of southeastern Angola.",70 Met een slag het hy die SAW se hele operasionele poging in die omgewing oos van Cuito Cuanavale bedreig. Vanuit die gebied waar sy troepe hulle nou gevestig het, was 'n groot flankbeweging in 'n oostelike rigting immers moontlik - dalk deur die noorde van Namibië; dalk noord van die grens aan die Angolese kant - om die Suid-Afrikaanse troepe van hul hinterland in Namibië af te sny. Wat die Suid-Afrikaanse politici nie wou toelaat nie, het Castro wel gedoen.

Agterna kan daar geen twyfel wees oor wat Castro se bedoeling was nie: dit was beslis nie om die konflik te eskaleer nie. Trouens, alles dui daarop dat hy botsings met die SAW wou vermy. Dit was nietemin 'n dreigement wat die Suid-Afrikaners ernstig móés opneem, en wat hul operasionele postuur gevolglik noodwendig moes raak. Dit was 'n blufspel, maar wat 'n manjifieke een! Dit was 'n uitstekende voorbeeld van Liddell Hart se ideaal om 'n oorwinning sonder gevegte te behaal, want dit het 'n groot rol gespeel in Suid-Afrika se beslissing om die gebied te ontruim.

Geldenhuys se gevolgtrekking is juis: "Ek en 'n paar ander het al hoe meer begin glo dat die Kubane aanvaar het dat hulle bondgenote 'n beslissende nederlaag in die suidooste gely het. Ook dat dit nie net die keerpunt van hierdie veldtog was nie, maar wel van die hele jarelange oorlog en dat hulle sou moes begin onderhandel. Onderhandeling kan egter tot troepeonttrekking lei, wat 'n mens nie graag met 'n verloorbeeld doen nie. daarom moes die beeld van die nederlaag by die Lombarivier verander word. Rondom die onderhandelingstafel wil 'n mens ook graag uit 'n posisie van sterkte praat. 'n Dreigende militêre houding in die suidweste sou dit bewerkstellig en boonop die aandag nog verder van die suidooste aftrek. ${ }^{71}$ 
Nietemin is die Suid-Afrikaners om verskillende redes heeltemal onkant betrap. Ten eerste kon hulle wel vermóéd het dat dit 'n blufspel was, maar hulle kon dit nie wéét nie. Dit sou onverantwoordelik wees om summier te aanvaar dat dit wel 'n blufspel was. In die tweede plek het die SAW in dié stadium haas geen konvensionele magte met swaar toerusting in die noorde van Namibië gehad nie; dié magte was meestal diep in Angola. As die Kubane dus in dié stadium die grens wou oorsteek, sou hulle die lig bewapende teeninsurgensie-eenhede in die omgewing eenvoudig opsy kon gevee het.

Dis teen dié agtergrond dat 'n taamlik sterk konvensionele mag, bestaande uit Burgermageenhede, in die noorde van Namibië gekonsentreer is. Maar dit het 'n week of twee, drie geduur om die troepe op te roep en daar te kry, heeltemal genoeg tyd vir die Kubane om te doen wat hulle wou - ás hulle sou wou.

Die opmars was dus 'n klassieke voorbeeld van die indirekte benadering. Castro het uiteraard self die krediet daarvoor opgeëis, maar of dit nou tereg was of nie, dit was 'n meesterskuif waarvoor 'n mens uit professionele oogpunt nie anders kan as om groot bewondering uit te spreek nie. Simon Barber se gevolgtrekking oor Castro se relaas lyk daarom in die kol: "This is not the story of a South African defeat. It is the story of an Angolan defeat and how, with considerable nerve and panache, the Cubans extricated themselves from it." ${ }^{, 72}$

Suid-Afrika se reaksie was rasioneel. P.W. Botha se opdrag aan die SAW was dat Suid-Afrika hom nie hierdeur in Angola moes laat insuig nie. "Laat die Kubane maar maak wat hulle wil, hou hulle dop, hou kontak, maar moenie 'n nuwe oorlog begin nie. Behou julle aggressiwiteit, maar moenie arrogant-parmantig wees nie. Wees koelkop en beoefen selfbeheersing.

"Maar, het pres. Botha gesê, as hulle 'n voet oor die grens sit, dan slaan julle hulle met alle mag en krag. As dit gebeur, dan word Ovaboland die nuwe slagveld."73

Uiteindelik was dit alles onnodig. Behalwe vir 'n enkele skerp geveg op 26-27 Junie tussen Kubaanse en Suid-Afrikaanse magte het albei met

Barber: "The Angolan Debacle by Fidel Castro" (Steenkamp: South Africa's Border War, p. 256.)

73 Geldenhuys: Dié wat wen, p. 191. 
groot selfbeheersing opgetree en mekaar vermy. Dit was trouens die laaste botsing van die veldtog. Die Suid-Afrikaanse magte is almal uit Angola onttrek; die onderhandelinge het op 'n omvattende vredesverdrag uitgeloop; die Kubane het hul tasse gepak en is huis toe; en die SuidAfrikaners het eweneens hul tasse gepak en Namibië het onafhanklik geword.

\section{WIE HET GEWEN?}

Fidel Castro, 'n meester-propagandis, het reeds kort ná die veldtog onomwonde die oorwinning vir hom opgeëis. Ná dese, het hy verkondig, sal die geskiedenis van Afrika geskryf moet word as dié vóór die SuidAfrikaanse nederlaag by Cuito Cuanavale en dié daarna. ${ }^{74}$ Met ander woorde, die Suid-Afrikaanse nederlaag was volgens hom só groot dat dit selfs ' $n$ nuwe fase in die geskiedenis van die vasteland ingelui het. Dit is 'n siening wat vandag nog by sommige ondersteuners van die ANC in Suid-Afrika voorkom.

Andersyds het genl. Malan die - na sy mening - Suid-Afrikaanse oorwinning só besing: "Die Weermag se militêre welslae is ongeëwenaar in moderne oorlogvoering. Met 'n mag wat nooit 3000 oorskry het nie, het die Weermag die Kubaanse en Angolese MPLA-magte bloedneus op bloedneus geslaan, veral by Lomba en Cuito Cuanavale in SuidoosAngola.

"Die Kubane veral, wat gedroom het van hoe hulle Pretoria gaan binnemarsjeer, het hul moses teengekom. Hulle en die MPLA-magte het 'n vernederende neerlaag gely ..."75

As daar verby dié soort propagandistiese uitsprake gekyk word, kan die saak op twee maniere benader word: militêr-strategies en nasionaalstrategies. Dit is 'n objektiewe maatstaf om te kyk na wat die doelstellings van die opponerende vegtende partye was en in welke mate dié doelstellings behaal is, al dan nie.

- Die Sowjet-Unie en die MPLA se militêr-strategiese doel was om Unita finaal uit te skakel, en sy operasionele doel om Mavinga te beset en Jamba daarvandaan te bedreig. Dit het totaal misluk. Nie

Vgl. Steenkamp: South Africa's Border War, p. 163. 
alleen is hulle tot vlakby Cuito Cuanavale teruggedryf nie, maar Unita het oorleef.

- Kuba se militêr-strategiese doel was bloot om 'n opening te vind waardeur hy hom aan die Angolese moeras kon onttrek. Sy operasionele doel was om die Suid-Afrikaners met sy suidwaartse opmars na die grens sodanig te bluf en te intimideer dat hy dit met eer kon doen. Hy het heeltemal daarin geslaag.

- Suid-Afrika se militêr-strategiese doel was aanvanklik om Unita te help om te oorleef en later om 'n omvattende vredesooreenkoms te verkry waardeur Kuba se aanwesigheid in Angola beëindig en Namibië onafhanklik kon word. Sy operasionele doel was aanvanklik om Fapla se opmars na Mavinga te stuit en later om Fapla tot oorkant die Cuito terug te dryf sodat hy nie weer in 1988 in staat sou wees om opnuut 'n offensief te begin nie. In die strategiese doelstellings is geslaag; in die operasionele doelstellings byna heeltemal: Fapla het net 'n bruggehoof by Tumpo oos van die Cuito behou.

Die gevolgtrekking lyk duidelik: militêr-strategies en operasioneel het die Sowjet-Unie en Fapla sleg verloor. Die Kubane het skitterend gewen. Suid-Afrika het teen die Sowjet-Unie en die MPLA grotendeels gewen verreweg nie met 'n uitklophou nie, maar met punte. Teen Kuba het hy verloor - eweneens nie met 'n uitklophou nie, maar met punte.

Nasionaal-strategies lyk sake anders. Ofskoon dit nie die eintlike doel van dié studie is nie, kan hieraan nie verbygegaan word nie. Die SowjetUnie, Kuba en die MPLA se doel was duidelik om die kommunisme in Angola, en liefs in Namibië ook, te vestig. Dit het hulle nie bereik nie. Veral Kuba, wat miljoene pesos en talle menselewens in Castro se idealistiese uitvoer van die revolusie belê het, moes kwaai op sy neus kyk. In die afwesigheid van insae in die relevante argivaliese bronne is ook Suid-Afrika se nasionaal-strategiese doel moeilik bepaalbaar, maar dit lyk of 'n uitspraak soos dié van Pik Botha, Minister van Buitelandse Sake, dat Suid-Afrika geen Swapo-oorwinning sou aanvaar wat tot Sowjet-Kubaanse aanwesigheid en invloed in Namibië sou lei nie ${ }^{76}$, na aan die kol kan wees. Hierin is geslaag, maar as die doel ook was om 'n 
onafhanklike Namibië as 'n Suid-Afrikaanse satellietstaat te handhaaf, het hy misluk. Bowendien, al was Castro se propaganda-aansprake feitelik sterk oordrewe, het die feit dat hy die propagandaoorlog loshande gewen het, gehelp om Pretoria en die SAW se aura van onoorwinlikheid aan te tas. En dit het die destydse Regering se onderhandelingsposisie sodanig verswak dat hy toegewings moes doen om vrede te kry, soos om uit Namibië pad te gee.

Uiteindelik is dit egter nie vreeslik relevant nie. Uit die vredesonderhandelinge het naamlik 'n nuwe konsep na vore getree, dat álmal moet wen en niémand verloor nie. Die kompromis wat uiteindelik bereik is, het genoeg voordele vir al die partye bevat dat elkeen die gevoel kon kry dat hy gewen het. "Victory in the true sense," skryf Liddell Hart, "implies that the state of peace, and of one's people, is better after the war than before." 77 Dit die eerste ondervinding wat die SuidAfrikaanse regering gehad het in werklike onderhandeling met 'n party wat nie sy mindere was nie, wat hy nie kon rondstamp soos hy wou nie. Dié nuwe ervaring het 'n belangrike rol gespeel om Pretoria intellektueel en emosioneel voor te berei op die onderhandelinge met die ANC wat enkele jare later hierop sou volg.

Só gesien, het almal iéts uit die saak gekry, al was dit nie presies wat hulle wou hê nie. En dalk was dit nog die beste moontlike uitslag denkbaar.

\section{PROPAGANDA}

Om te bepaal wie 'n oorlog gewen het, veral as die uitslag nie op 'n totale oorwinning soos dié van 1945 vir die Geallieerdes oor Duitsland en Japan uitloop nie, is egter nie alleen die feite nodig nie. Persepsies, wat gevoed word deur propaganda, is byna net so belangrik. Reeds die Assiriese koning Assoernasirpal het in die negende eeu v.C. inskripsies agtergelaat om te spog oor sy ontsaglike oorwinnings oor sy vyande, terwyl uit ander bronne (onder meer die Ou Testament) soms blyk dat die "oorwinnings" dikwels eintlik nederlae of onbesliste gevegte was. 
Soos vroeër gestel is, was Fidel Castro 'n meester in propaganda, en hy het alles in die werk gestel om die Angolese veldtog as 'n skitterende oorwinning vir hom en sy bondgenote en 'n yslike nederlaag vir SuidAfrika en Unita af te skilder. Castro se mededelings oor die oorlog was die eerstes wat die wêreld ingestuur is, onder meer dat tientalle SuidAfrikaanse vliegtuie neergeskiet is, ensovoorts. Dat die berigte onjuis was, het nie veel beteken nie: die Kubane was eerste met hul propaganda, en dit het vir punte getel.

Die persepsie wat hierdeur ontstaan het, is ook gevoed deur onafhanklike waarnemers. Castro het naamlik dadelik die kans aangegryp om Westerse joernaliste na die front by Menongue en Cuito Cuanavale te laat kom om die wêreld in te lig oor wat daar aan die gang was.

Die joernalis Pascal Fletcher van die nuusagentskap Reuter het byvoorbeeld verskeie artikels van die front gestuur, wat wêreldwyd in koerante - ook enkeles in Suid-Afrika ${ }^{77}$ - gepubliseer is. Nog $\mathrm{n}$ voorbeeld was die Amerikaner Karl Maier ${ }^{78}$, wat sy waarnemings aan die front later in 'n boek oor Angola geïnkorporeer het.

Dié soort verslae was nie noodwendig propagandisties nie en ook nie noodwendig simpatiek teenoor die MPLA en die Kubane nie. Maar die blote feit dat joernaliste verslag gedoen het oor wat aan die Kubane en MPLA se kant van die frontlinies gebeur het, het gehelp om persepsies te kleur.

Andersyds het dit geblyk dat die Suid-Afrikaanse regering en die SAW nie veel van oorlogspublisiteit begryp het nie. Die eerste SAWdokument om sy kant van die saak te stel, is eers begin 1988 uitgereik. $^{79}$ Ook het die SAW nie die moeite gedoen om die Kubane se voorbeeld te volg en onafhanklike joernaliste na die front te neem nie. Reeds in dié vroeë stadium het die SAW die propaganda-oorlog dus hopeloos verloor - en daarmee is die hardnekkige mite dat die Weermag sleg pak slae in Angola gekry het, sodanig gevestig dat talle mense dit vandag nog glo.

Vgl. bv. The Argus, 16.4.1988.

Vgl. Karl Maier: Angola: Promises and Lies, hoofstuk 2.

Breytenbach: "Cuito Cuanavale Revisited" (Africa Insight, 27/1 1997, pp. 65 en 66). 


\section{OPERASIONELE RIGLYNE}

Al wat nou nog oorbly, is om die krygshandelinge van Suid-Afrika, Fapla en Kuba aan algemeen aanvaarde operasionele beginsels te toets. Liddell Hart het nege riglyne neergelê waaraan operasionele behandelinge behoort te voldoen. ${ }^{80} \mathrm{Kom}$ ons kyk na elkeen en pas hulle dan op bogenoemde drie partye toe.

- Adjust your end to your means. Dit beteken basies dat jy jou doel nie te hoog moet stel nie; dat jy nie meer moet probeer bereik as waartoe jy in staat is nie.

Suid-Afrika het heeltemal hieraan voldoen. Hy het trouens slegs 'n fraksie van sy militêre vermoëns gebruik. Een punt.

Die MPLA het hom sleg ooreis. Sy militêre doktrines is van die Sowjets oorgeneem en het nie die werklikhede van 'n bosoorlog in Afrika in ag geneem nie. Die Sowjet-wapentuig het nie bevredigend gefunksioneer nie. En Fapla se troepe was sleg opgelei en gemotiveer. Geen punte.

Kuba voldoen hieraan as slegs die veldtog van 1987-'88 in aanmerking geneem word. Maar sy hele betrokkenheid by die konflik in Angola was militêr onrealisties. Dit was in der waarheid Kuba se eie Viëtnam. 'n Halfpunt dus.

- Keep your object always in mind - 'n beginsel waarop Harry Summers ook groot klem lê, aangesien "all else flows from it. At the tactical and operational levels of war it defines the mission to be achieved. And at the strategic level ... the objective, by defining the ends to be attained, is literally half of the strategic equation." Effens verder gaan hy in tipies Clausewitziaanse terme voort: "The objective determines the war's value, and it is this value against which the corts of war are to be assessed ..." ${ }^{, 11}$ Dit is belangrik om geen onduidelikheid by jou eie politici en soldate te laat bestaan oor wat jy wil bereik nie.

Suid-Afrika voldoen heeltemal hieraan. Geldenhuys skryf: "As mnr. (pres.) Botha klaar gepraat het, het jy nie getwyfel oor wat hy wil hê nie. Hy wou nie 'n 'Viëtnam' gehad het nie. Ons moes ons missie uitvoer en 
uit Angola onttrek." En elders: "Soos gewoonlik het 'n mens weer presies geweet wat P.W. Botha wou gehad het." ${ }^{82}$ Een punt.

Die MPLA het aanvanklik eweneens 'n duidelike doel - die uitskakeling van Unita - voor oë gehad. Later was dit bloot die oorlewing van sy troepe in die veld. Omdat hy egter al gou die inisiatief verloor het, het die duidelikheid van sy doelstelling egter betreklik irrelevant geword. 'n Halfpunt.

Kuba se doel was ook onomwonde, naamlik onttrekking uit Angola met eer, en liefs op só 'n wyse dat hy op 'n oorwinning aanspraak kon mak. Die opmars na die Namibiese grens het dié doel op 'n skitterende wyse gedien. 'n Volle punt.

- Choose the line (or course) of least expectation.

Suid-Afrika het sleg hierin gefaal. Aan die begin van die veldtog het hy nagelaat om Fapla onkant te betrap deur om sy regterflank, waar laasgenoemde dit nie verwag het nie, te beweeg. Die Suid-Afrikaners se opmars van die Lomba na die omgewing van Cuito Cuanavale was voorspelbaar en regstreeks. Hulle kry geen punte nie.

Die MPLA het eweneens sleg gefaal. Sy herhaalde opmarse van Cuito Cuanavale in die rigting van Mavinga het telkens dieselfde roete gevolg en is dus telkens met groot verliese teruggeslaan. Hy kry geen punte nie.

Kuba se opmars na die grens het in uitnemende mate hieraan voldoen, wat aan hom 'n punt besorg.

- Exploit the line of least resistance. Presies dieselfde opmerkings as by die vorige punt is hier ook geldig. Met ander woorde, geen punte vir Suid-Afrika en die MPLA nie en 'n punt aan Kuba.

- Take a line of operation which offers alternative objectives. Die doel hiervan is om jou vyand aan die raai te hou sodat hy nie weet wat jy wil doen nie. "Put your opponent on the horns of a dilemma," is die stelreël van die Amerikaanse genl. William T. Sherman uit die Amerikaanse Burgeroorlog wat Liddell Hart hier aanhaal.

Suid-Afrika se besluit om sy operasies oos van die Cuito te handhaaf en Fapla se terugtrekking na Tumpo het beteken dat hy homself tot één doel beperk het, naamlik Tumpo. Dus kon Fapla dié omgewing op sy tyd 
in 'n onneembare vesting omskep. Onderweg daarheen het die SuidAfrikaners hul teenstanders wel takties aan die raai gehou. ' $n$ Halfpunt.

Met die aanvang van sy offensief het die MPLA op 'n lomp manier aan dié riglyn probeer voldoen deur ' $n$ afleidingsopmars uit Lucusse suidwaarts te begin, maar dit het die Suid-Afrikaners of Unita nooit mislei nie. Daarna was daar nooit twyfel oor waarheen die Faplabrigades gemik het nie - Mavinga. Geen punte.

Weer eens moet Kuba 'n volle punt kry. Met 50 Divisie naby die Namibiese grens in Suid-Angola ingegrawe, kon hulle drie dinge doen: (a) daar bly; (b) Namibië binneval; of (c) binne Angolese grondgebied ooswaarts trek om die Suid-Afrikaanse magte by Tumpo af te sny. Die Suid-Afrikaners was hier beslis "on the horns of a dilemma": hulle het vermóéd dat die Kubane met ' $n$ blufspel besig was, maar hulle kon dit nie wéét nie.

- Ensure that both plan and dispositions are flexible - adaptable to circumstances.

Daar kan geen twyfel wees dat Suid-Afrika net gedeeltelik hieraan voldoen nie. Hy hét buigsaamheid aan die dag gelê deur sy verdedigende oorwinnings aan die Lomba met ' $n$ offensief op te volg en sy operasionele doelstelling uit te brei, maar die feit dat hy nie soepel genoeg kon dink deur die volkome onverwagte te doen en wes van die Cuito op te marsjeer nie, gee die land hier net ' $n$ halfpunt.

Die MPLA het ná sy nederlae in die suide hoofsaaklik op die inisiatiewe van sy opponente gereageer. Dat hy die Suid-Afrikaners uiteindelik by Tumpo kon terughou, is - as ' $n$ mens Castro se relaas kan glo - egter nie aan Luanda te danke nie, maar aan Havana. Dus geen punte nie.

Weer eens voldoen Kuba ruimskoots aan die riglyn. 'n Punt.

- Do not throw your weight into a stroke whilst your opponent is on guard.

Wie dié studie se vertolking aanvaar, sal saamstem dat Suid-Afrika hier nie meer as ' $n$ halfpunt kan kry nie. Sy aanvanklike aanvalle op die Fapla-brigades aan die Lomba het laasgenoemdes totaal onkant betrap. Daarna het sy frontaanvalle verder noordwaarts oorwegend plaasgevind met Fapla deeglik vooraf daarop bedag. 
Dit is waar dat nóg Suid-Afrika nóg Unita in 1987 'n offensief van Fapla verwag het. Maar dit het taamlik gou duidelik geword wat sy planne was, en sy offensief het hom dus vasgeloop teen opponente wat hom verwag het. Geen punte nie.

Dit raak nou al amper vervelig, maar Kuba se opmars na die Namibiese grens het Suid-Afrika sleg onkant getref. Een punt.

- Do not renew an attack along the same line (or in the same form) after it has once failed.

Suid-Afrika verdien opnuut geen punte nie. Die besluit om oos van die Cuito te bly het herhaalde frontaanvalle teen Fapla in die omgewing vereis, waarvan die laaste drie in dieselfde onmiddellike omgewing was. 20 SA Brigade het weliswaar probeer sorg dat hy takties aan dié riglyn voldoen, maar met inagneming van die operasionele beperkings wat deur die Regering gestel is, was dit in die omstandighede onmoontlik.

Ook die MPLA moet sonder punte bly. Al sy offensiewe sedert begin jare tagtig het min of meer dieselfde voorspelbare roete gevolg, ondanks die mislukking van die voriges.

In dié geval is die stelreël nie op Kuba van toepassing nie, eenvoudig omdat sy troepe geen aanvalle uitgevoer het nie.

Die uitslag is nogal opvallend. Kuba loop los voor met 6,5 punte uit 'n moontlike 7 (93\%), dan volg Suid-Afrika met 4,5 uit 'n moontlike 8 (56\%), en Angola kom agteraan met slegs 'n halfpunt uit 'n moontlike 8 $(6 \%)$. Vir Suid-Afrika is dit eenvoudig nie goed genoeg nie, en die land kan hom gelukkig ag dat hy nog so goed uit die Angolese veldtog getree het.

Dié persentasietoekenning moet uiteraard nie in dieselfde lig as die uitslag van 'n algebratoets beskou word nie; dit gee slegs 'n algemene aanduiding van hoe goed die drie partye hul troepemagte operasioneel gehanteer het. Tog, hopelik leer die nuwe SANW en die nuwe regering hieruit hoe om die Weermag wél en nié te gebruik nie.

Heitman het daarom gelyk: "The South Africans managed to bring about a total change in both the strategic and political situation in southeastern Africa by die carefully controlled application of limited force. Operation Moduler and the ensuing campaign are an excellent illustration of war as an instrument of politics: the deployment of a small force 
operating under very close political control achieved the political end that had eluded the diplomats for years." 83

Die onbevredigende punte wat Suid-Afrika behaal het, is gedeeltelik te wyte aan die feit dat die Suid-Afrikaanse top-offisiere waarskynlik geen voldoende insig in die teoretiese beginsels van oorlogvoering had nie. Baie van die flaters wat in oorloë begaan word, sê die Amerikaanse vloothistorikus Philip Crowl, "have been, at root, failures of the imagination, failures of the intellect." $\$ 4$

Anette Seegers skryf tereg: "From the time of Union, debates about the Department of Defence held that military experience counted more than intellectual or staff ability. Staff courses and later joint staff courses at the Defence College favoured those with operational experience, the line officers. The SADF wanted innovative soldiers. The abstractions of staff officers would spoil them. Even for its elite, the SADF thought theory best ignored." ${ }^{\circ 5}$ Dit geld ook vir die stief behandeling wat die studie van krygsgeskiedenis deur die jare dikwels aan die Militêre Akademie gehad het. ${ }^{86}$

Sedertdien het sake wel begin verander. In 1991 het die Militêre Akademie vir die eerste keer ' $n$ kursus in strategie begin aanbied. Ook die feit dat die skrywer van dié studie deesdae herhaaldelik lesings by die Vlootstafkollege oor 'n teoretiese onderwerp soos die geopolitiek aanbied, dui op 'n kentering.

Tog is die ou kultuur nog lank nie dood nie. Volgens persoonlike mededelings is daar steeds offisiere wat deur meerderes meegedeel word dat dit hul loopbaan sal skaad as hulle dosente aan die Militêre Akademie word. En ná 'n gedetailleerde ondersoek kom G.E. Visser tot die gevolgtrekking "dat daar in die SANW, strydig met die praktyk in ander moderne weermagte, nie volle erkenning verleen word aan die sleutelposisie wat 'n kennis van die krygsgeskiedenis ten opsigte van militêre professionalisme beklee nie". ${ }^{87}$

Heitman: War in Angola, p. 347.

Aangehaal in Kotzé: "Die Strategiese Kontinuum" (Joernaal vir Eietydse Geskiedenis, 19/3, Des. 1994, p. 38).

Annette Seegers: The Military in the Making of Modern South Africa, p. 141.

Vgl. hieroor G.E. Visser: "Militêre Professionalisme en die Onderrig van Krygsgeskiedenis in die Suid-Afrikaanse Nasionale Weermag: 'n Historiese Perspektief' (Scientiae Militaria, vol. 27, 1997, pp. 15-36).

Ibid., p. 36. 
Vergelyk dit met die situasie in Amerika: daar het 'n sekere kapt. Harry McMaster, 'n pantseroffisier in die Golfoorlog, 'n aanval op tenks van die Irakse Revolusionêre Garde gelei. Sy aanval het volgens Tom Clancy "one of the most studied battles of modern times" geword, "the Battle of 73 Easting". Clancy sê "the Army and General Fred Franks (the commander of VII Corps), were so impressed with the results of the fight that a team of analysts from the U.S. Army's Institute for Defense Analysis came out to study every aspect of the battle in order to reconstruct it for future training and use back in the United States. From this has come a computer model of the entire battle, which is considered on a par with textbook operations such as Joshua Lawrence Chamberlain's defense of Little Round Top at Gettysburg (in die Amerikaanse Burgeroorlog) and Major John Howard's capture and defense of Pegasus Bridge on D-Day (die Geallieerde landing in Normandië in 1944)." $" 88$

Dieselfde kapt. McMaster - iemand van wie 'n mens kan aanneem dat sy beroepspad boontoe ooplê - het ná sy oorsese dienstyd verkies om dosent in die krygsgeskiedenis aan West Point, die Amerikaanse leër se militêre akademie, te word. Klaarblyklik beskou die Amerikaanse militêre 'n behoorlike akademiese en teoretiese onderlegdheid van hul beroep as 'n voordeel, nie as 'n nadeel nie. ${ }^{89}$

Goed, daar kan dalk aangevoer word dat die oorlog en mannekragtekort dit in die jare sewentig en tagtig nie toegelaat het dat gevegsoffisiere dosente aan die Militêre Akademie word nie. Maar dit het die SAW se offisiere nie onthef van die plig om 'n behoorlike studie van die strategie en krygsgeskiedenis te maak nie. En sonder die beperkings van oorlog geld so 'n argument natuurlik glad nie meer nie.

Uiteindelik is die onderskeid tussen teorie en praktyk in elk geval grotendeels ongeldig. Enige goeie teorie is gebaseer op praktiese ondervinding, en 'n weiering om die waarde van militêre teorie te erken is om eeue se praktiese ondervinding te ontken.

Die slotwoord is dus aan Mao Zedong: "Alle militêre wette en teorieë wat in die vorm van beginsels voorkom, is die ondervinding van verbye oorloë wat opgesom word deur mense in die verlede of in die hede. Ons 
moet dié lesse, waarvoor met bloed betaal en 'n erfenis van verbye oorloë is, ernstig bestudeer. Dit is een punt. Maar daar is nog een. Ons moet dié gevolgtrekkings aan ons eie ondervinding toets, assimileer wat nuttig is, verwerp wat onbruikbaar is, en byvoeg wat spesifiek ons eie is." 90 Waar die veldtog in Angola min of meer as "ons eie ondervinding" kan geld, sal dié vermaning hopelik ter harte geneem word.

\section{BIBLIOGRAFIE}

Barber, James en John Barratt: South Africa's Foreign Policy, The search for status and security 1945-1988. Cambridge, 1990.

Beaufre, André: Strategy for Tomorrow. Stanford, 1974.

Bond, Brian: Liddell Hart, A Study of his Military Thought. Londen, 1976.

Breytenbach, W,: "Cuito Cuanavale revisited: Same outcomes, different consequences" (Africa Insight 27/1, 1997).

Bridgeland, Fred: The War for Africa, Twelve Months that Transformed a Continent. Gibraltar, 1990.

Clancy, Tom: Armoured Warfare, a Guided Tour of an Armoured Cavalry Regiment. Londen, 1994.

Clausewitz, Carl von: On War (Vom Kriege). Vertaal deur kol. F.N. Maude. Londen, 1940.

Crocker, Chester A.: High Noon in Southern Africa, Making Peace in a Rough Neighborhood. Johannesburg, 1992.

Du Preez, Sophia: Avontuur in Angola, die verhaal van Suid-Afrika se Soldate in Angola 1975-'76. Pretoria, 1989.

Geldenhuys, Jannie: Dié wat wen, 'n Generaal se storie uit ' $n$ era van oorlog en vrede. Pretoria, 1993.

Heitman, Helmoed-Römer: War in Angola, the Final South African Phase. Gibraltar, 1990.

Kotzé, J.S.: "Die Strategiese Kontinuum: Raamwerk vir 'n Studie van Suid-Afrikaanse Strategie in die Namibiese Konflik" (Joernaal vir Eietydse Geskiedenis, 19/3, Des. 1994). 
Liddell Hart, Adrian (red.): The Sword and the Pen, Selections from the world's greatest military writings. Londen, 1976.

Liddell Hart, Basil H.: Strategy. New York, 1954.

Maier, Karl: Angola: Promises and Lies. Rivonia, 1996.

Mao Zedong: "Problems of Strategy in China's Revolutionary War" (Selected Military Writings of Mao Tse-tung). Beijing, 1968.

Pottinger, Brian: The Imperial Presidency, P.W. Botha - the first 10 years. Johannesburg, 1988.

Seegers, Annette: The Military in the Making of Modern South Africa. Londen, 1996.

Spies, F.J. du T.: Angola, Operasie Savannah 1975-1976. Pretoria, 1989.

Steenkamp, Willem: Borderstrike! South Afriea into Angola. Durban/Pretoria, 1983.

Steenkamp, Willem: South Africa's Border War, 1966-1989. Gibraltar, 1989.

Summers, Harry G.: On Strategy, A Critical Analysis of the Vietnam War. New York, 1984.

Summers, Harry G.: On Strategy II, A critical Analysis of the Gulf War. New York, 1992.

Sun Tzu: The Art of War. Vertaal deur Thomas Cleary. Boston, 1988.

Visser, G.E.: "Militêre Professionalisme en die Onderrig van Krygsgeskiedenis in die Suid-Afrikaanse Nasionale Weermag: 'n Historiese Perspektief" (Scientiae Militaria, vol. 27, 1997).

Wallach, Jehuda L.: Das Dogma der Vernichtungsslacht, die Lehren von Clausewitz und Schlieffen und ihre Wirkungen in zwei Weltkriegen. Frankfurt am Main, 1967. 


\title{
Die Suid-Afrikaanse Nasionale Vredesmag in Militêre Perspektief
}

\author{
PROF LEO BARNARD EN ME SUNET SWANEPOEL \\ Departement Geskiedenis, U.O.V.S., Bloemfontein
}

\section{SUMMARY}

The release of Nelson Mandela in 1990 was the turning point in the democratisation process of South Africa, because the first free and fair election was declared in April 1994. This led to the establishment of the national Peace Force which had to assure that the first democratic election in the country would indeed be free and fair. The Peace Force was disrupted by various problems from the beginning. The first of which was the appointment of Gabriel Ramushwana as commander, who was no success. These problems were enhanced during the training process of the recrutes who would serve in the peaceforce. They not only had to be trained in the limited period of six weeks, which was impossible to achieve, but the fact that the recurters were associated with defferent structures and organisations, resulted in huge disagreements that could not be bridged. During the first deployment of the National Peaceforce, it was clear that they were not fit for the task and before long they disappeared into oblivion.

\section{DIE TOTSTANDKOMING EN ROL VAN DIE VREDESMAG}

Die vrylating van Nelson Mandela in 1990 was 'n keerpunt in die geskiedenis van Suid-Afrika. Dit het die weg gebaan vir die demokratiseringsproses in dié land. Onderhandelings tussen onder andere die Nasionale Party (NP) en die African National Congress (ANC) vir die hervorming van die Suid-Afrikaanse politieke bestel het 